\title{
Репрессивная деятельность бригады Каминского на оккупированных территориях СССР в 1941-1944 гг.
}

\begin{abstract}
Аннотация статьи: В статье российских историков Д.А. Жукова и И.И. Ковтуна раскрываются проблемы, связанные с карательной деятельностью руководства Локотского окружного самоуправления и бригады РОНА на оккупированных территориях РСФСР и Белоруссии в 1941-1944 гг. В публикации рассматриваются такие важные аспекты, как борьба с советскими партизанами и подпольем, идеологические установки русских коллаборационистов, в частности - антисемитизм и полонофобия, а также исследуется вопрос преступлений в отношении гражданского населения и коллаборационистов, пожелавших вернуться на советскую сторону.
\end{abstract}

Outline of content: The article reveals the problems associated with punitive activities of the leadership of the Lokotskaya self-governing district and the S.S. Sturmbrigade RONA in the occupied territories of the RSFSR and Belarus in 1941-1944. The study addresses such important aspects as the fight against Soviet partisans and the underground, the ideological attitudes of Russian collaborators, in particular anti-Semitism and Polonophobia, and also investigates the issue of crimes against the civilian population and collaborators who wished to return to the Soviet side.

Ключевые слова: Коллаборационизм - Карательные акции - Борьба с партизанами Б.В. Каминский и РОНА - Антисемитизм - Преступления против гражданского населения

Keywords: Collaborationism, punitive actions, struggle against partisans, B.V. Kaminski and RONA, anti-Semitism, crimes against the civilian population

Немецкий эксперимент по созданию на оккупированных территориях РСФСР и БССР коллаборационистских органов власти и вооруженных формирований Б.В. Каминского (1899-1944) остается одной из дискуссионных проблем в современных исследованиях и публицистических сочинениях о Второй мировой войне ${ }^{1}$. По своему масштабу и результатам

${ }^{1}$ См., в т.ч., нашу работу: Жуков Д.А., Ковтун И.И. 29-я гренадерская дивизия СС «Каминский». М., 2009. 304 с. 
проделанной работы в деле установления «нового порядка» автономные округа, подчиненные Каминскому (с осени 1941 г. - Локотская волость, район и округ на юге Брянщины, с сентября 1943 г. до мая 1944 г. - Лепельский округ в Белоруссии ${ }^{2}$, не имеют аналогов в истории русского коллаборационизма.

По данным американского исследователя А. Даллина, разрешение на проведение этого опыта в марте 1942 г. дал лично А. Гитлер - с подачи командования группы армий «Центр» ${ }^{3}$. При оформлении своих вооруженных формирований (изначально отрядов «народной милиции», с осени 1942 г. - Русской освободительной народной армии, ставшей в итоге 29-й дивизией войск СС; в литературе также часто встречается наименование «бригада Каминского») глава автономии пользовался покровительством и поддержкой вермахта и СС. При этом, в отличие от более известного русского коллаборациониста А.А. Власова, он не был просто марионеткой в руках у нацистских пропагандистов и обладал действительными властными полномочиями. В свою очередь, Каминский оказывал немецким и венгерским оккупантам существенную вооруженную поддержку в борьбе с советским партизанским движением.

Часть отечественных историков и публицистов склонна рассматривать военно-гражданскую деятельность Каминского с сугубо положительной точки зрения, фактически показывая Локотскую и Лепельскую автономии в качестве реальной альтернативы сталинской диктатуре ${ }^{4}$. Эти исследователи чрезвычайно подробно описывают различные аспекты восстановления гражданской жизни, отрицают, что «государство» Каминского и его партия (Народная социалистическая партия «Викинг», затем - Национал-социалистическая трудовая партия России) строились по нацистским лекалам - включая антисемитскую практику - и вообще предпочитают не затрагивать репрессивно-карательную деятельность каминцев.

Их оппоненты, напротив, стараются вовсе не касаться каких бы то ни было успешных инициатив Каминского и сосредотачиваются исключительно на преступлениях военнослужащих («народников», или «роновцев», как их именовали

2 В октябре 1941 г. в Брасовском районе Орловской области было сформировано самоуправление (Локотская волость) под руководством К.П. Воскобойника (1895-1942). Вплоть до его гибели, вопреки распространенным мифам, деятельность самоуправления мало чем отличалась от «нового порядка», установленного в других оккупированных сельских районах РСФСР. Только после того, как самоуправление возглавил Каминский, привилегии местных коллаборационистов были постепенно расширены. С мая 1944 г. Каминским было предпринято несколько попыток по созданию самоуправлений в других районах (в том числе, в белорусском Дятлово), но по военным причинам они успехом не увенчались.

3 Даллин А. Бригада Каминского. М., 2011. С. 30.

${ }^{4}$ См., напр.: Веревкин С.И. Самая запретная книга о Второй мировой. Была ли альтернатива Сталину? М., 2009. 608 с.; Ермолов И.Г. Русское государство в немецком тылу. История Локотского самоуправления. 1941-1943. 252 с. 
в партизанских документах) и чиновников автономии ${ }^{5}$. К сожалению, большинство подобных работ следует признать идеологически обусловленными, а потому поверхностными (хотя и не лишенными ценного фактического материала) и искажающими некоторые эпизоды . Поэтому будет вовсе не лишним объективно и более подробно остановиться на репрессиях каминцев против своих военных и политических противников, а также мирного населения.

Одновременно с этим немаловажной представляется тема преступлений в среде самих коллаборационистов. Не в полной мере исследован также вопрос о том, сколько «народников» перешло к партизанам и сколько бойцов РОНА было убито Каминским и его подчиненными, когда попытки перехода не удавались? Недостаточно раскрытой, с нашей точки зрения, остается проблема распространения антисемитизма среди каминцев.

Следует оговориться, что значительную часть источников, касающихся карательной практики автономии и ее вооруженных формирований, нельзя признать совершенно надежной. Речь, прежде всего, идет о различных партизанских донесениях и актах районных чрезвычайных комиссий по расследованию злодеяний немецко-фашистских захватчиков и их сообщников. В этих документах число жертв часто преувеличивалось; некоторые случаи убийств и насилия по отношению к местному населению со стороны партизан приписывались коллаборационистам. Более достоверными надо назвать немецкие оперативные документы, а также анонимные интервью бывших каминцев, проведенные в рамках Гарвардского проекта по опросу советских беженцев (имена многих из респондентов к настоящему моменту установлены исследователями).

\section{Против партизан и «бандпособников»}

В октябре 1941 г. с разрешения командования 17-й танковой дивизии вермахта бургомистр Локотской волости (до войны - Брасовский район Орловской области), бывший преподаватель местного техникума К.П. Воскобойник, приступил к формированию вооруженных отрядов «народной милиции». Эти отряды состояли из антисоветски настроенных уроженцев района и красноармейцев-окруженцев. В их задачи входило обеспечение охраны германских тыловых коммуникаций и борьба с отдельными партизанскими отрядами (до определенного момента малочисленными и неактивными) ${ }^{6}$.

Согласно иной трактовке событий, первые вооруженные отряды и партия «Викинг» были организованы Воскобойником и Каминским без санкции

5 См., напр.: Христофоров В.С. Коллаборационисты отдельно взятого Локотского округа // 65 лет Великой Победы. В 6 т. Т. 4: Другое лицо войны. М., 2010. С. 179-211.

${ }^{6}$ Pohl D. Die Herrschaft der Wehrmacht. Deutsche Militärbesatzung und einheimische Bevölkerung inder Sowjetunion. Frankfurt-am-Main, 2011. S. 180. 
немцев. Это подтверждает отчет тылового района 2-й танковой армии от 7 февраля 1942 г., где среди прочего отмечается: «Самостоятельное образование сильных вооруженных отрядов местных жителей или иных групп с собственной политически неконтролируемой программой - к примеру, национал-социалистической партии “Викинг” к югу от Навли - новое явление, которое вне сомнений заслуживает внимания... Неизвестно, соответствуют ли цели этой партии целям немецкого политического руководства... Эти лица фанатичны, заряжены энергией и способны добиться заметного влияния»7. В итоге, немцы начали оказывать реальную поддержку русским антикоммунистам лишь тогда, когда партизаны заметно активизировались.

25 ноября 1941 г. Воскобойник выпустил приказ, обращенный к партизанам. Бургомистр предлагал им сдать оружие старостам близлежащих сел и явиться в Локоть группами по два-три человека для регистрации: «Пора давно прекратить безобразие и приступить к организации мирной трудовой жизни». При этом декларировалось, что слухи о поголовном истреблении партизан и коммунистов являются «вздорными». Суровые меры Воскобойник грозил применить лишь против «самых злонамеренных представителей партийного и советского аппарата, которые не хотят сами и не дают возможности другим стать на мирный трудовой путь». Приказ был подписан: «Руководитель Народной социалистической партии инженер Земля (КПВ)» ${ }^{8}$.

В ответ на коллаборационистскую деятельность Воскобойника и его заместителя, бывшего инженера местного спиртзавода Каминского, партизанские отряды под командованием А.Н. Сабурова в ночь на 8 января 1942 г. совершили дерзкое нападение на Локоть, в результате которого бургомистр был тяжело ранен и скончался. Власть перешла в руки к Каминскому. Немцы нашли в последнем «хорошего помощника»; в одном из документов он характеризовался так: «Каминский... управляет своим районом, опираясь на авторитет своей личности, и показывает себя верным соратником немцев, которые пришли в Россию, чтобы освободить народ от большевизма» 9 . Каминский поклялся отомстить за смерть Воскобойника ${ }^{10}$. Вместе со своим заместителем С.В. Мосиным они организовали расстрел 7 заложников, обвиненных в связях с партизанами ${ }^{11}$.

7 ЦАМО Ф. 500. Оп. 12454. Д. 558. Л. 207-211. Документ переведен и опубликован в своем блоге (http://labas.livejournal.com) мюнхенским историком И. Петровым.

8 Приказ К. Воскобойника. 25 ноября 1941 г. Фотокопия // Даллин А. Указ. соч. С. 22.

9 Даллин А. Указ. соч. С. 26.

10 Report by the Foreign Office Liaison Officer attached to $2^{\text {nd }}$ Army Headquarters, Rittermeister Graf Bossi Fedrigotti, Concerning the National-Socialist Russian Battle Group Kaminski in Lokot near Navlya // Michaelis R. The Kaminski Brigade. Schiffer Military History, 2011. P. 83.

11 Христофоров В.С. Коллаборационисты отдельно взятого Локотского округа // 65 лет Великой Победы. В 6 т. Т. 4: Другое лицо войны. М., 2010. С. 184. 
Чтобы в дальнейшем исключить нападения на Локоть и уничтожить «бандитов» в своих владениях, Каминский провел мобилизацию мужчин от 18 до 50 лет в ряды «народной милиции». В докладной записке начальника особого отдела НКВД Центрального фронта Л.Ф. Цанавы от 20 марта 1943 г. говорилось: «Формирование полицейских батальонов, проводимое Каминским и Балашовым, до второй половины 1942 г. было основано на принципах добровольчества. Контингентом для вербовки служили изменники Родины из числа военнопленных, дезертиры Красной армии, оставшиеся на оккупированной территории, и лица, проявившие недовольство Советской властью» ${ }^{12}$. Впрочем, по мнению исследователя М. Рябоконя, за уклонение от мобилизации был якобы предусмотрен расстрел ${ }^{13}$.

Вербовочные мероприятия сопровождались активной пропагандистской кампанией. 9 февраля Каминский выпустил обращение, в котором главными врагами русского народа объявлялись коммунисты: «Эти гады... еще в мирное время пили русскую благородную кровь. Это они... довели русский народ до нищеты и голода, это они... десятки миллионов русских людей отправили в концлагеря, где эти мученики и умирали. Не один десяток миллионов женщин и детей оставили без крова и пищи. А эти псы пировали на этих трупах зверски замученных людей. Они, во главе со своим кровожадным кретином Сталиным, кричали о хорошей жизни, ибо они жили, а народ бедствовал. Пора кончить проливать кровь» ${ }^{14}$.

В конечном итоге, с помощью агитации и угроз, Каминскому удалось набрать более 1400 человек, которых распределили по четырем батальонам. 11 марта 1942 г. бургомистр издал приказ для своих вооруженных отрядов. Он объявил, что если партизаны попадутся с оружием в руках, то никому из них пощады давать не следует ${ }^{15}$ В апреле подразделения локотской милиции, наряду с частями 102-й и 108-й венгерских дивизий, подчинили начальнику 532-го тылового района генерал-лейтенанту Фридриху Густаву Бернхарду. В том же месяце коллаборационистов направили на зачистку Комаричского района ${ }^{16}$.

12 См.: «Огненная дуга»: Курская битва глазами Лубянки. М., 2003. С. 244. Бойцов РОНА в партизанских документах часто именовали «полицаями». В то же время, наряду с «народной милицией» в округе действовала и собственно полиция.

13 Рябоконь М.В. Против партизан Брянщины // «Военно-исторический журнал» (Москва). 2004. № 4 (528). С. 22.

14 Цит. по: Ермолов И.Г. История Локотского округа и Русской освободительной народной армии. Орел, 2008. С. 125-126.

15 To the police battalions of the Lokoty District, 11 March 1942 // Michaelis R. The Kaminski Brigade. Schiffer Military History, 2011. P. 75.

16 Протокол допроса генерал полковника Р. Шмидта, 2 апреля 1948 г. // Генералы и офицеры вермахта рассказывают... Документы из следственных дел немецких военнопленных. 1944-1951. М., 2009. С. 158. В марте 1942 г. силы коменданта 532-го тылового района насчитывали всего около 5600 человек. См.: Stopper S. Das Brjansker Gebiet unter der 
К началу весны 1942 г. немецкие охранные войска уже отработали на практике некоторые приемы борьбы с партизанами. В принципе, эти методы немногим отличались от тех, которые германская армия использовала еще в период Франко-прусской и Первой мировой войн (расстрелы инсургентов $^{17}$ и сочувствовавшего им населения, сожжение непокорных деревень, захват заложников и т.д. $)^{18}$.

По тому же пути шли и венгерские войска, действовавшие совместно с милицией Каминского. В аналитическом обзоре 4-го отдела Венгерского королевского Генерального штаба об опыте боев с партизанами (апрель 1942 г.) особое внимание было уделено применению карательных мер: «Вслед за поражением партизанских отрядов должно последовать самое неумолимое и безжалостное возмездие. Нет места снисхождению. Немилосердная жестокость у всякого отнимает охоту, чтобы впредь присоединиться к партизанам или поддерживать их... Взятых в плен партизан подвергнув, в случае нужды, опросу, тут же на месте надо прикончить (расстрелять) либо, для устрашения, где-нибудь в ближайшем селе надо публично повесить» ${ }^{19}$.

Перед венгерскими частями и отрядами Каминского были поставлены задачи по блокированию для партизан выходов из Брянских лесов. Эти мероприятия, как сообщается в документах, сопровождались сожжением населенных пунктов и убийством нелояльных гражданских лиц. В частности, 15 апреля 1942 г. венгерские военнослужащие при поддержке полиции уничтожили село Угревище. Огнем было разрушено 100 домов, 5 конюшен, 5 амбаров, колхозный клуб, церковь и здание сельского магазина. Были расстреляны 55 человек. В последующие дни, когда зачистка продолжилась, было сожжено 600 домов в селах Война и Игрицкое, были сожжены деревня Кубань, поселки Марс, Большевик, Ленинец и Молчан. Население, проживавшее здесь, было частично уничтожено, частично отправлено в трудовые лагеря ${ }^{20}$.

Согласно венгерским донесениям, 102-я дивизия и 46-й пехотный полк 105-й пехотной бригады («Бауманская группа») в апреле 1942 г. ликвидировали 1380 партизан и их сообщников, в то время как собственные потери

Besatzungsherrschaft der Wehrmacht 1941 bis 1943. Dissertation zur Erlangung de akademischen Grades Doctor philosophiae. Berlin, 2012. S. 32.

17 Инсургенты (буквально - «повстанцы») - вооруженные отряды гражданского населения, противостоящие властям.

${ }^{18}$ Hasenclever J. Wehrmacht und Besatzungspolitik in der Sowjetunion. Die Befehlshaber der rückwärtigen Heeresgebiete 1941-1943. Paderborn, 2010. S. 382.

19 Аналитический обзор 4-го отдела Венгерского королевского Генерального штаба об опыте боев с партизанами, апрель 1942 г. // Великая Отечественная война. 1942 год: Исследования, документы, комментарии. М., 2012. С. 598.

20 Краткий очерк о партизанском движении в Комаричском районе (октябрь 1941 - апрель 1943 г.). Утвержден 12 мая 1943 г. бюро Комаричского райкома ВКП(б). Копия // Личныцй архив И.И. Ковтуна; Из акта Комаричской районной комиссии от 20 июня 1944 г. // ГАБО. Ф. 6. Оп. 1. Д. 54. Л. 150. 
венгерских войск составили более 50 человек убитыми, 67 пропавшими без вести и 99 раненых. При этом борьба с партизанами часто сводилась к расправам над населением, сохранявшим лояльность советской власти ${ }^{21}$.

В мае 1942 г. немецкие войска нанесли несколько сильных ударов по брянским партизанам. В тылу 2-й танковой армии под началом командира 216-й пехотной дивизии генерал-лейтенанта Фрайхерра фон унд цу Гильза была сформирована боевая группа, куда включили части действующей армии. Кроме того, группа «Гильза» (около 15 тыс. человек) активно использовала части, находившиеся в тактическом подчинении у 532-го тылового района, - венгерские войска и локотскую «народную милицию» 22 .

Формирования Каминского не только помогали оккупантам находить партизанские лагеря и стоянки, вели разведку, поиск жителей, скрывавшихся в лесах, но и сами принимали активное участие в боях ${ }^{23}$. В одном из партизанских донесений (от 31 июля 1942 г.) сообщалось: «Наступление ведется цепями. В первой линии идут полицейские, за ними мадьяры и в последней линии немцы» 24 .

В мае-июне 1942 г. тыловые органы 2-й танковой армии предприняли несколько локальных акций, а затем провели крупную операцию «Птичье пенье II» (Vogelsang II). Зачистке подверглись Суземский, Комаричский, Навлинский и Брасовский районы. Каждая операция сопровождалась разрушением населенных пунктов и расправами над противниками «нового порядка». По итогам акции «Птичье пенье II» были убиты 1193 партизана, 1400 ранены, 498 захвачены в плен, из окрестных деревень выселены более 12 тысяч жителей ${ }^{25}$. Со слов очевидцев тех событий, проживавших в Суземском районе, карателям стало известно, что значительная часть населения скрылась в лесах. Для захвата этих людей было организовано дополнительное прочесывание.

${ }^{21}$ Варга Е.-М. Венгрия в войне против СССР: события 1942 г. // Великая Отечественная война. 1942 год... С. 92.

${ }^{22}$ Michaelis R. Russen in der Waffen-SS... S. 11.

23 Утверждение Христофорова, что «в операциях отряды Каминского выступали в качестве проводников и разведчиков, наводя карателей на партизанские тагеря и ушедших в лес мирных жителей» (См.: Христофоров В.С. Локотское окружное самоуправление: правда и вымысел // Великая война и Великая Победа народа. К 65-летию победы в Великой Отечественной войне: в 2 кн. Кн. II. М., 2010. С. 284), не совсем верно отражает реальную картину. Тактическое подчинение предполагает непосредственное участие в боевых действиях.

${ }^{24}$ РГАСПИ. Ф. 69. ОП. 1. Д. 909. Л. 12. О непосредственном участии отрядов Каминского в боевых действиях говорят и немецкие документы. Так, в журнале дежурного офицера штаба коменданта тылового района 2-й танковой армии в записи от 5 июня 1942 г. отмечалось «Начальник Локотской милиции Каминский настоятельно просит помощи. По всему его фронту наступают силы партизан. Потери: 50 убитых и 120 раненых. Срочно нужны боеприпасы для винтовок и перевязочный материал». См.: Под немцами. Воспоминания, свидетельства, документы. Историко-документальный сборник. СПб., 2011. С. 479.

${ }^{25}$ Варга Е.-М. Указ. соч. С. 96. 
Пойманных в лесу граждан отправляли в лагеря. Семьи партизан и подозреваемых в связях с «бандами» расстреливали ${ }^{26}$.

В июле 1942 г. на территории Брасовского и соседних с ним районов проводилась серия локальных акций под кодовым наименованием «Зеленый дятел» (Grünspecht). Всего до середины сентября 1942 г. было проведено 9 операций под этим названием ${ }^{27}$. Только до начала августа группа «Гильза» зачистила в общей сложности 80 деревень ${ }^{28}$.

5 августа 1942 г. Каминский через газету «Голос народа» обратился к партизанам и населению волостей, зараженных «бандитизмом». Он говорил о новой акции, а также о том, какая участь ждет тех, кто не сдастся: «С целью лишения бандитов экономической базы будут сжигаться все населенные пункты, в которых находятся партизаны. Население будет эвакуировано, а семьи партизан будут уничтожены, если их родственники (отцы, братья и сестры) не перейдут к нам до 10 августа с.г.» ${ }^{29}$.

Объявленные Каминским зачистки завершились сожжением нелояльных населенных пунктов и массовым убийством их жителей. Партизаны обратили внимание на следующие факты поведения немецких и венгерских войск: «Каратели сжигают все занятые в ходе боя населенные пункты. Население этих пунктов поголовно расстреливается. При этом изверги-фашисты проявляют жестокие зверства, прежде чем расстреливать. Грудных детей сажают на штыки, женщин насилуют, вырезают груди и многих живьем зарывают в землю. Население уходит в леса вместе с партизанскими отрядами» ${ }^{30}$. Справедливости ради следует сказать, что сами «народные мстители» совершенно не брезговали совершать преступления против человечности, в частности убивали женщин и детей - членов семей коллаборационистов. При этом использовались совершенно запредельные методы: отрубание пальцев рук и ног, выкалывание глаз, протыкание шомполами ушей и т.д. ${ }^{31}$ В любом случае, противостояние между коллаборационистами и противниками «нового порядка» как на Брянщине, так и на других оккупированных территориях, носило чрезвычайно жестокий характер.

Анализ немецких трофейных документов, захваченных партизанами, а также допросов бывших бойцов РОНА позволяет утверждать, что в ходе операции «Зеленый дятел» милиция Каминского не только вместе с немцами сжигала деревни, но и делала это самостоятельно. В суточном донесении 2-й танковой армии о действиях партизан за 9 сентября 1942 г. говорилось, что операция «Зеленый дятел IX» завершена полным разрушением сел

${ }^{26}$ Из акта Суземской районной комиссии от 10 мая 1944 г. // ГАБО. Ф. 6. Оп. 1. Д. 54. Л. 85.

27 Bandenmeldung 8.9.42 // ЦАМО. Ф. 500. Оп. 12454. Д. 428. Л. 267.

${ }^{28}$ Michaelis R. Russen in der Waffen-SS...S. 12.

29 Обращение // «Голос народа» (Локоть). 1942. № 14, 5 августа. С. 3.

30 РГАСПИ. Ф. 69. Оп. 1. Д. 909. Л. 12.

31 См.: Соколов Б.В. Оккупация. Правда и мифы. М., 2002. С. 178. 
Шушуево, Крапивна и Алтухово 32 . В протоколе допроса перебежчиков из бригады РОНА встречается более подробная информация: «За оказание помощи партизанам и связь с ними бригадой полностью сожжены деревни Красная Слобода, Требушка, Чернь, Гаврилова Гута, Кокоревка, Кокушкино, Чухра, Смилиж, Игрицкое, Добровольский, Алтухово, Шушуево и другие. Население сожженных деревень переселилось в деревни, расположенные вне лесов» ${ }^{33}$.

Исследователь А. Даллин замечает, что обращение каминцев с населением, сочувствовавшим партизанам, принимало чрезвычайно экстремальные формы. Он, в частности, пишет, что «если люди отказывались подчиняться приказам РОНА, их... “наказывали, избивали и расстреливали”... Как впоследствии вспоминал один военнослужащий бригады: "Когда мы входили в какую-нибудь деревню, мы узнавали, кто из ее жителей связан с партизанами. После этого мы изымали у этих жителей скот. Мы старались грабить только дома, в которых жили коммунисты и семьи партизан. Иногда эти семьи уничтожались" ${ }^{34}$.

В середине сентября - в начале октября 1942 г. германское командование провело в Навлинском районе операции «Треугольник» (Dreieck) и «Четырехугольник» (Viereck). В течение двух недель партизаны вели ожесточенные бои против немецких частей и подразделений «народников». В отчете партизанских бригад южной оперативной группы в Центральный штаб партизанского движения (ЦШПД) сообщалось: «В результате проведенной карательной экспедиции противнику удалось прочистить северный лесной массив, заставить партизанские отряды отойти за р. Навля, уничтожить школы, больницы и другие учреждения и провести жестокую расправу над мирным населением, пожечь 18 сел и 26 поселков» ${ }^{35}$.

Согласно актам чрезвычайных комиссий, составленных после освобождения этих территорий, действия немцев и военнослужащих РОНА носили безжалостный характер. Так, в акте Навлинской районной комиссии утверждается, что в селе Вздружном 19 сентября были расстреляны и замучены 132 человека, у села Глинное 17 сентября - 59, у деревни Ворки Салтановского сельсовета - 137, в селе Творишино были сожжены в сарае 99 женщин, стариков и детей. В селе Салтановка были расстреляны, сожжены и брошены в колодцы 103 человека. Такая же участь постигла 97 жителей поселка Ждановка. В деревне Зелепуговка были расстреляны 37 человек ${ }^{36}$.

В сообщении 2-й танковой армии от 6 октября 1942 г. отмечалось, что на территории Комаричского, Севского и Дмитриевского районов было

32 РГАСПИ. Ф. 625. ОП. 1. Д. 39. Л. 317.

33 РГАСПИ. Ф. 69. Оп. 1. Д. 750. Л. 108.

34 Даллин А. Указ. соч. С. 36.

35 РГАСПИ. Ф. 625. Оп. 1. Д. 39. Л. 277.

36 Из акта Навлинской районной комиссии от 15 октября 1945 г. // ГАБО. Ф. 6. Оп. 1. Д. 54. Л. 122. 
проведено переселение 18 тыс. человек (принудительная эвакуация рассматривалась как мера, позволяющая снизить уровень поддержки партизан со стороны местных граждан). Подозреваемых в симпатиях к советской власти доставляли в Локоть. Мужчин, оказывавших сопротивление, переводили в «особый лагерь» 37 .

Помимо крупных операций, на территории автономии летом-осенью 1942 г. проводились небольшие акции силами местной полиции. Например, одно из полицейских подразделений 29 августа 1942 г. сожгло поселок Сохрошин Хутор в Михайловском районе ${ }^{38}$. В том же районе полиция при участии немцев расстреляла всех жителей поселка Погорелый. Деревни Веретено, Звезда и Разветье были сожжены вместе с населением. Аналогичным образом действовали стражи порядка из села Коростовка Севского района, уничтожившие деревни Борисово, Бересток и поселок Лемешок.

В Севском районе активно боролся с партизанами и проводил репрессии 10-й батальон РОНА (командир - бывший лейтенант Красной Армии, поволжский немец Андрей Рейтенбах). 1-я и 2-я роты батальона, как сообщали органы НКВД, отличались «большой жестокостью по отношению к населению». 1-й ротой командовал осетин Довгазов, бывший военнослужащий РККА. За успехи, проявленные в боях с партизанами, Каминский отметил его подразделение в лучшую сторону и переименовал в «команду СС». Такой же была и 2-я рота батальона. Ее командир, бывший лейтенант РККА Хмелев, «жестоко расправлялся с партизанами и лицами, сочувствовавшими им» ${ }^{39}$.

19 июля 1942 г. приказом командующего 2-й танковой армии генерал-полковника Рудольфа Шмидта Локотский уезд преобразовали в округ. Территория, за которую отвечал Каминский, расширилась и там следовало установить соответствующий порядок. В состав самоуправления вошли Дмитриевский, Дмитровский и Михайловский районы оккупированной Курской области. С сентября до середины ноября 1942 г. здесь проводились разные по своему масштабу и количеству привлеченных сил и средств операции, в том числе «Хюсекен» I и II (Hüsecken) и «Хубертус» $\left(\right.$ Hubertus ${ }^{40}$.

В докладной записке заместителя начальника ЦШПД от 8 декабря 1942 г. приводились следующие данные: «За период сентябрь-октябрь и частично ноябрь 1942 г. войсками оккупантов (немцами, венграми) и полицией полностью сожжены населенные пункты Курской области: Дедеведье, Нижняя и Верхняя Кубань, Хлебтовский, Лобановский, Сипновский, Осиповский,

37 РГАСПИ. Ф. 625. Оп. 1. Д. 32. Л. 37, 352. Перевод с немецкого.

38 Из дневника Троснянского партизанского отряда Первой Курской партизанской бригады // «Орловский Военный Вестник» (Орел). 2013. № 4-5. С. 97.

39 «Огненная дуга»... С. 245, 344.

40 Anlage VI. Aufstellung der Antipartisanenoperationen 1941 bis 1943 im Brjansker Raum // Stopper S. Op. cit. S. 196. 
Подвойный, Чемерки, Кудачки, Дерюгинский, Круглинский, Северный, Восточный, Средний, Западный, Образцовый, Карпеевский, Студенский, Веселый, Средний - все на юго-западе от города Дмитровск, а также: Брянцево, Чистое, Петровский, Долбенкино, Горки, Погорелое, Веретенино, Опажье, Авилово, Новая Жизнь, Рясник, Медовый, Михайловский, Андреевский, Макарово - все на юго-востоке от города Дмитровск и ряд других ${ }^{41}$.

По неполным данным, в октябре-ноябре 1942 г. в Михайловском и Дмитриевском районах были преданы огню 32 деревни и села (1092 двора), расстреляны 870 лиц, сочувствовавших партизанам. В частности, в деревне Рясник Михайловского района были уничтожены 39 человек. В селе Погорелое в огне пожаров погибли 47 человек. В деревне Макарово были заживо сожжены 14 и расстреляны 19 человек. 19 октября 1942 г. в поселке Большой Дуб боевые группы по борьбе с партизанами расстреляли и сожгли 99 человек. В селе Веретенино погибли 115 человек, в поселке Холстинка - $125^{42}$.

Из партизанских мемуаров можно узнать, как проводились расправы в деревнях Веретенино, Черняково, в поселках Погорелое, Большой Дуб, Алексеевский, Холстинка, Новая Жизнь, Пролетарский, Рясник и Михайловский. Если верить словам бывшего комиссара 1-й Курской партизанской бригады А.Д. Федосюткина, немцы и военнослужащие РОНА окружали населенные пункты и собирали все население. Мужчин загоняли в сараи и на глазах семей сжигали заживо. Детей, женщин и стариков расстреливали в балках и оврагах ${ }^{43}$. Из показаний А.И. Михеева, начальника лесного отдела автономии, следует, что личный состав 13-го батальона РОНА, принимавший участие практически во всех этих акциях, сжег, кроме сел Большой Дуб, Макарово, Холстинка и Веретенино, поселок Хохли, деревню Жадеевка и село Уголек ${ }^{4}$.

20 ноября 1942 г. Каминский прибыл на прием к командующему 2-й танковой армии Рудольфу Шмидту. Генерал поблагодарил обер-бургомистра за его достижения в борьбе с «бандами» и выразил удовлетворение тем, как налажена работа в округе ${ }^{45}$. Каминский получил разрешение провести очередную мобилизацию годных к военной службе мужчин, чтобы сформировать из них новые батальоны и полки. Учитывая, что к концу 1942 г. дела у вермахта на ряде участков Восточного фронта пошли не самым лучшим образом, генерал-полковник Шмидт, безусловно, был заинтересован в том,

${ }_{41}$ РГАСПИ. Ф. 69. ОП. 1. Д. 909. Л. 156.

42 Манжосов А.Н. Политика репрессий фашистских оккупантов на территории Курской области (1941-1943 гг.) // «Курский край» (Курск). 1999. № 4 (7). С. 48.

43 Федосюткин А.Д. На земле железной // Народные мстители. Воспоминания курских и белгородских партизан и подпольщиков. Воронеж, 1975. С. 24.

44 Христоборов В.С. Коллаборационисты отдельно взятого Локотского округа... С. 199-200.

45 Прием у Главнокомандующего армии // «Речь» (Орел). 1942. № 137 (167), 22 ноября. С. 3. 
чтобы высвободить больше немецких частей для своей армии, а задачи по ведению борьбы с «бандитизмом» возложить в значительной мере на местных добровольцев. К 1943 г. Каминскому удалось довести численность РОНА до 12 тысяч человек (5 полков) ${ }^{46}$.

Параллельно с мобилизацией на территории округа продолжались акции против партизан и сочувствовавшего им населения. К этому времени обозначилось сотрудничество Каминского с СС. В Локте расположилась оперативная команда службы безопасности (СД), которая, как зафиксировано в рапорте доктора Гюнцеля, занималась «государственными и уголовными преступлениями» ${ }^{47}$. Кроме того, сотрудники СД постоянно выезжали вместе с «народниками» на операции. В отчете об оперативной деятельности айнзатцгруппы «Б» за период с 15 ноября по 15 декабря 1942 г. отмечалось: «В конце ноября команда СД Локтя в составе 4 человек вместе с милицией Каминского участвовала в зачистке от бандитов населенных пунктов Неварь, Хлебтовский и Кубань. Бандиты оставили 42 убитых. 31 бандит был арестован. 100 коров и 40 овец были захвачены. Местность, которая до этого находилась без какой-либо защиты, занята милицией. В отчетный период наблюдалось большое количество отдельных лиц, сочувствующих бандам, в отношении которых принимались соответствующие меры» ${ }^{48}$.

Зимой 1942-1943 гг. наиболее неспокойными районами Локотского округа считались территории, входившие в состав треугольника Дмитровск - Дмитриев - Михайловка (северо-западные районы Курской области). Партизаны 1-й Курской бригады спланировали операцию по захвату узловой станции Дерюгино. В ночь на 2 января 1943 г. они штурмом взяли железнодорожный узел. Местные подразделения РОНА позже отбили станцию, но движение эшелонов было прервано на трое суток ${ }^{49}$.

Партизанская активность вызвала озабоченность у тыловых органов 2-й танковой армии и в Локоть была направлена боевая группа полковника Карла Рюбзама. Группа «Рюбзам» (около 2800 чел.), состоявшая из 9 «охотничьих» команд, саперного взвода и милицейских отрядов, имела своей задачей прочесать район Михайловка - Дерюгино - Дмитровск и уничтожить «бандитов» ${ }^{50}$. Запланировано было три операции, получившие в немецких

46 РГАСПИ. Ф. 69. Оп. 1. Д. 750. Л. 103.

47 Report by Senior Military Administrator Dr. Günzel Concerning the Self-governed District of Lokot 25 May 1943 // Michaelis R. The Kaminski Brigade. Schiffer Military History, 2011. P. 111.

48 Tätigkeits-und Lagebericht Einsatzgruppe B für die Zeit vom 15.11-15.12.1942 // Mallmann K.-M., Angrick A., Matthäus J., Cüppers M. Deutsche Besatzungsherrschaft in der UdSSR 19411945. Dokumente der Einsatzgruppen in der Sowjetunion. Bd. II. Darmstadt, 2013. S. 496-497.

49 Коровин В.В. Партизанское движение на территории Курской области в 1941-1943 гг. Курск, 2006. С. 88.

${ }^{50}$ Fernschreiben von Okdo.H.Gr. Mitte an OKН Gen.St.d.H. / Op.Abt., 7.1.1943 // ЦАМО. Ф. 500. Оп. 12451. Д. 69. Л. 116. 
документах кодовое наименование «Белый медведь» (Eisbär I, II und III). СД, наблюдавшая за тем, как проводились эти акции, посчитала их провальными. Разрушив около 120 блиндажей и землянок, группа «Рюбзам» упустила партизан, не сумев, как было подчеркнуто в отчете, «приспособиться к боевым методам бандитов. Банды в течение двух дней сумели уйти в лесные районы вокруг Севска, и их уже нельзя было окружить» ${ }^{51}$.

Во время операции «Белый медведь» вновь совершались преступления против просоветски настроенного населения. При этом, как отмечала газета «Голос народа», германские войска и бойцы РОНА обнаружили в оставленных «бандитских» лагерях «трупы расстрелянных и зверски замученных людей: с отрубленными конечностями, без голов и распоротыми животами» ${ }^{52}$. Вообще, пропаганда каминцев уделяла «преступлениям бандитов» (действительным или мнимым - сегодня установить невозможно) очень большое внимание. В феврале 1943 г. локотский «официоз» сообщил, что во время казни людей «партизаны отрубали им топором ноги, половой член и голову в области лба. Подобные рода зверства не вкладываются ни в какие рамки преступлений перед русским народом» ${ }^{53}$. Понятно, что такого рода информация еще более ожесточала военнослужащих РОНА.

В ходе советского наступления в феврале-марте 1943 г. вооруженные формирования Локотской автономии впервые участвовали в боях против частей Красной армии, в частности при обороне Севска. По приказу германского командования подразделения РОНА были повзводно и поротно влиты в немецкие и венгерские части, а в каждый батальон каминцев были направлены германские офицеры. Большая часть жителей была привлечена на работы по строительству оборонительных сооружений. Согласно приказу Каминского, «рабочих и служащих, дезертировавших с трудового фронта, в условиях напряженной военной обстановки», разрешалось привлекать «К судебной ответственности и по законам военного времени» ${ }^{54}$.

Дмитриев-Севская наступательная операция советских войск в итоге окончилась провалом. Вокруг Севска отдельные бои продолжались до середины апреля. В ходе боевых действий погибли более 15 тысяч советских кавалеристов и лыжников ${ }^{55}$. Командующий 2-й танковой армией генерал-полковник Р. Шмидт направил Каминскому письмо, в котором отмечал:

51 Tätigkeits- und Lagebericht Einsatzgruppe B für die Zeit vom 16.-31.1.1943 // Mallmann K.-M., Angrick A., Matthäus J., Cüppers M. ...Bd. II. S. 518.

52 На местном фронте. Борьба с бандитизмом // «Голос народа» (Локоть). 1943. № 5 (43), 31 января. С. 1.

53 «Голос народа» (Локоть). 1943. № 6 (44), 7 февраля. С. 1.

${ }_{54}$ Выписка из приказа № 39 по Локотской бригаде Народной Армии от 10 марта 1943 г. // РГАСПИ. Ф. 625. Оп. 1. Д. 45. Л. 282.

55 Подробнее об участии РОНА в этой операции см.: Жуков Д.А., Ковтун И.И. 29-я гренадерская дивизия СС «Каминский»... С. 105-116. 
«Благополучному исходу происходивших событий мы многим обязаны Вам и Вашей способной Народной Армии» ${ }^{56}$.

Красная армия повторно освободила Севск только 27 августа 1943 г. При этом, в акте районной чрезвычайной комиссии по расследованию злодеяний немецко-фашистских оккупантов и их пособников, среди прочего, указывалось, что в городе были найдены захоронения гражданских лиц и «военнопленных» (194 человека). Судя по всему, под последними подразумевались погибшие в ходе мартовского штурма Севска бойцы Красной армии, впоследствии захороненные вместе с гражданскими жертвами городских боев ${ }^{57}$.

Распространенным явлением в Локотском округе была практика захвата заложников. Этот метод был позаимствован у германских коллег и от случая к случаю использовался местными полицейскими и военными структурами. При этом современный немецкий историк С. Штоппер не видит в системе заложничества какого-либо геноцида славян и относит подобные действия к жесткой реакции оккупационных властей на угрозу партизанского движения ${ }^{58}$.

По словам Штоппера, «местная “полиция” в Локте захватывала заложников и пыталась таким образом сдерживать атаки партизан. Если происходили нападения, убийства полицейских или гражданских лиц, то независимо от того, сколько было потерь, отбиралось, как правило, бо́льшее число заложников и расстреливалось» ${ }^{59}$. Каминскому приходилось брать заложников, чтобы снизить активность партизан на коммуникациях, но эффект от этого был небольшой. Из аналитического отчета бывшего полковника вермахта Хассо Нойцеля видно, что борьба за коммуникации в тылу 2-й танковой армии в 1942-1943 гг. доставляла немецким органам большую головную боль: «Сильные банды партизан располагались в лесах к западу от Локтя... Банды, обосновавшиеся в этих лесах, проводили постоянные нападения на автомобильные и железнодорожные пути, шедшие в Рославль. Поэтому немецкие линии коммуникации в так называемом Орловском выступе были открыты для партизанских атак со всех сторон; неприятные последствия такого положения вещей вскоре стали чувствоваться при проведении операций по снабжению» ${ }^{60}$.

Захват заложников также осуществлялся в тех случаях, когда руководство округа стремилось ответить на террор со стороны партизан. Например, 6 февраля 1943 г. администрация автономии направила командирам партизанских отрядов ультиматум: «С сего дня за каждого замученного бойца,

56 Ермолов И.Г. История Локотского округа... С. 153.

57 ГАРФ. Ф. Р-7021. Оп. 19. Д. 2. Л. 102. В том же акте указано, что в 1941-1943 гг. в Севске были расстреляны и повешены 70 граждан, 118 человек погибли от артобстрела и бомбардировок (надо полагать, в том числе Красной армии), 80 человек «угнаны в немецкое рабство в Германию».

58 Stopper S. Op. cit. S. 169.

59 Ibid. S. 170.

${ }^{60}$ Neitzel H. Rear Area Security in Russia. Washington, 1951. P. 24-25. 
старосту или более ответственных работников - расстреливать заложников из расчета за каждого бойца, старосту - 20 партизан-заложников; за каждого командира и ответработника - 50 партизан-заложников». Данное предупреждение особой роли не сыграло, поскольку уже 18 февраля было совершенно покушение на заместителя обер-бургомистра, С.В. Мосина. В результате были расстреляны 40 заложников-партизан ${ }^{61}$.

Бывший заместитель командира бригады и полковник РОНА Георгий Белай вспоминал: «Начальник следственного отдела и одновременно главный судья, Процюк, отличался особой жестокостью. Он был садистом, лично бил женщин, пинал их ногами, и т.д. Каминский знал об этом, но в течение длительного времени не вмешивался. У нас было политическое управление, которое выпускало воззвания к партизанам и вело пропаганду на советскую сторону (наши листовки сбрасывались с немецких самолетов). Из пропагандистских соображений необходимо было помиловать нескольких захваченных партизан. Но Процюк регулярно убивал их или приговаривал к тюремному заключению на срок от 5 до 10 лет. Очень немногим удалось вырваться из его когтей» ${ }^{62}$.

Также практиковалась передача пленных партизан и подпольщиков (по два-три человека) в полки бригады РОНА, где их расстреливали - очевидно, для острастки личного состава и для того, чтобы предотвратить переходы бойцов к партизанам ${ }^{63}$.

Казни нелояльных граждан и захваченных в плен партизан совершались в окружной тюрьме Локтя. Первоначально тюрьма размещалась в общежитии лесохимического техникума, а затем с августа 1942 г., была переведена в помещения бывшего конезавода № $17^{64}$. Наиболее зловещую репутацию здесь заработала женщина-палач Антонина Парфенова (она же Макарова, она же Гинзбург, также известна как «Тонька-пулеметчица»). Разумеется, исполнителем смертных приговоров была не только она, но и другие тюремные служащие. В котловане, расположенном в 300-400 м. от конезавода, были расстреляны около 2000 человек ${ }^{65}$.

61 Заявление из газеты «Голос народа» от 5 марта 1943 г. // Под немцами... С. 487. В акте о преступлениях немецко-фашистских захватчиков в Брасовском районе от 27 сентября 1945 г. эти заложники были названы «мирными жителями». См.: ГАБО. Ф. 6. Оп. 1. Д. 54. Л. 16. После войны Мосин показал на допросе: «В марте 1943 г. за покушение на меня было расстреляно в качестве заложников 40 советских граждан... Вообще же военно-полевым судом было приговорено к повешению и расстрелу более 200 советских граждан... Мною приговорено лишь 13-14 партизан к смертной казни». См.: Варшавское восстание 1944 г. в документах из архивов спецслужб. Варшава-М., 2007. С. 1190.

${ }^{62}$ Harvard Project on the Soviet Social System (HPSSS). Schedule B, Vol. 11, Case 321. 16.XII.1950. P. 8.

63 Христофоров В.С. Коллаборационисты отдельно взятого Локотского округа... С. 189.

64 Там же. С. 188.

${ }^{65}$ ГАБО. Ф. 6. Оп. 1. Д. 54. Л. 16. 
Каминский, согласно показаниям перебежчиков из РОНА, довольно часто появлялся в тюрьме, принимал участие в допросах и пытках ${ }^{66}$. Уроженка Севского района Евдокия Подпоркина вспоминала: «В 1942 г. в феврале месяце сын взял меня в Красный лес в партизаны... Я отстала от своих и осталась в лесу одна. 7 июня утром попала к немцам в плен.. 8 июня нас, 20 человек мужчин и 2 женщин, отправили в Локоть, где сняли допрос. Допрашивал нас начальник полиции Каминский». По словам Подпоркиной, обер-бургомистр заставлял ее «насильным путем рассказать, как я попала к ним [к партизанам. - Примеч. авт.]. Меня полицейские били... но я все равно им правды не рассказала, т.к. меня они бы могли сразу же на месте пристрелить. После допроса меня отправили в Брасово, где сидело 3 тыс. человек в концлагере» ${ }^{67}$.

Наивысшего накала борьба с партизанами достигла во время подготовки германским командованием операции «Цитадель», на которую возлагались большие надежды. Чтобы обеспечить успешное проведение готовящегося наступления летом 1943 г., штаб группы армий «Центр» заранее спланировал и провел ряд карательных экспедиций в районах Брянска, Витебска, Бобруйска и Могилева ${ }^{68}$. Наиболее крупной из них являлась операция под кодовым названием «Цыганский барон» (Zigeunerbaron) против партизанских сил, дислоцировавшихся в лесах южнее Брянска ${ }^{69}$.

Общая численность немецких войск, привлеченных к этому мероприятию, доходила до 40 тысяч солдат и офицеров. Для уничтожения партизан было выделено 4 полка из бригады $\mathrm{POHA}^{70}$. Перед началом операции, 11 мая 1943 г., командование 2-й танковой армии издало приказ об эвакуации гражданского населения. К мероприятиям были привлечены и формирования Каминского. Так, обер-бургомистр получил право наравне с представителем штаба боевой группы «Рюбзам» определять, какая территория подлежит полному очищению и эвакуации. Кроме того, в Локоть необходимо было свезти всех заразных больных, после чего они должны были пройти медицинский осмотр под надзором врача XVII танкового корпуса. Людей, захваченных в ходе зачисток, следовало отправлять в сборные лагеря, организованные вдоль железнодорожной линии Локоть - Брянск ${ }^{71}$.

66 РГАСПИ. Ф. 69. Оп. 1. Д. 750. Л. 104.

${ }^{67}$ ГАРФ. Ф. Р-7021. Оп. 19. Д. 43. Л. 26, 27. Подпоркину продержали в лагере 3 недели, после чего она была эвакуирована на запад, где работала в качестве сиделки и домашней прислуги у русских эмигрантов. После войны была репатриирована на Родину.

68 Азясский Н. О кладе партизан в разгром группы армий «Центр» // «Военно-исторический журнал» (Москва). 1980. № 2. С. 32.

69 Anlage VI. Aufstellung der Antipartisanenoperationen 1941 bis 1943 im Brjansker Raum // Stopper S. Op. cit. S. 197.

70 Дробязко С.И. Под знаменами врага. Антисоветские формирования в составе германских вооруженных сил 1941-1945 гг. М., 2004. С. 214.

71 ГАРФ. Ф. 7445. Оп. 2. Д. 156. Л. 174-175. 
В период операции «Цыганский барон» подчиненные Каминского выполняли разные карательные задачи. Помимо уже указанной эвакуации населения из районов партизанской активности, проводились расстрелы. Например, в парк поселка Навля, обнесенного колючей проволокой, согнали захваченное население, подозреваемое в связях с партизанами. Затем из парка люди вывозились на машинах в урочище Трусова Гора (в 2 км от Навли). Около большака Навля - Брасово позже были обнаружены 276 трупов. В районе урочища Разделиц 26 мая 1943 г. были расстреляны 106 человек $^{72}$. Расстрелы также проводились в Суземке, где были убиты до 400 человек $^{73}$.

За время операции «Цыганский барон» (с 15 мая по 6 июня 1943 г.) были убиты 1584 «бандита», 1568 взяты в плен, 869 дезертировали. Было уничтожено 207 лагерей, 2930 землянок и огневых точек, привлечены к суду более 2400 «бандпособников», часть из которых были расстреляны ${ }^{74}$. В общей сложности были захвачены 15812 подозреваемых ${ }^{75}$.

Наряду с операцией «Цыганский барон» штаб группы армий «Центр» почти одновременно спланировал и осуществил операции «Помощь соседу» (Nachbarhilfe I und II) и «Вольный стрелок» (Freischütz). К операции «Вольный стрелок» (с 19 по 28 мая 1943 г.) подключили батальоны Каминского. В рамках этой акции проводились мероприятия по замирению занятой территории. Жертвами акции стали 1419 человек из числа сочувствовавшего партизанам гражданского населения, 13 деревень было сожжено, 317 домов разрушено. В расправах участвовал и личный состав $\mathrm{POHA}^{76}$.

В середине июля 1943 г. стало очевидно, что операция «Цитадель» провалилась. Каминский и его окружение начали подготовку к отступлению вместе с немецкими войсками. 5 августа самоуправление выпустило приказ № 233 об эвакуации военных и гражданских учреждений Локотского округа, а также местных жителей, не желавших вновь оказаться под властью большевиков. По немецким данным, на территорию оккупированной Белоруссии выехало около 6000 солдат и 25 тысяч гражданских лиц, в основном членов

72 ГАБО. Ф. 6. Оп. 1. Д. 54. Л. 123.

73 ГАБО. Ф. 6. ОП. 1. Д. 54. Л. 85.

${ }^{74}$ Cooper M. Nazi war against Soviet partisans. New York, 1979. Р. 153. По данным ЦШПД после проведения операции «Цыганский барон» немцы и коллаборационисты потеряли убитыми, ранеными и пленными 3952 человека. Потери партизан убитыми, ранеными и пропавшими без вести составили 2096 человек. См.: РГАСПИ. Ф. 69. Оп. 1. Д. 71. Л. 32 об.; Д. 790. Л. 176.

75 Штоппер С. Смерть немецким оккупантам? О военной эффективности партизанского движения в немецко-советской войне (по немецким источникам на материалах Брянского региона) // Доклады академии военных наук. № 3 (38). Саратов, 2009. С. 169.

76 Howell M.E. The Soviet Partisan Movement, 1941-1944. Washington, 1956. P. 158-159; Prag W., Jacobmeyer W. Das Diensttagebuch des deutschen Generalgouverneurs in Polen 1939-1945. Stuttgart, 1975. S. 128. 
семей каминцев, сотрудников автономии и население, поддерживавшее коллаборационистов ${ }^{77}$.

В период проведения эвакуации по округу прокатилась очередная волна преступлений. Местные органы власти старательно избавлялись от свидетелей. Так, заместитель обер-бургомистра Мосин, участник сожжения населенных пунктов Крупец, Шемякино, Гавриловка, Холмечи, Красный Колодец, Хутор Холмецкий, Бендирка, - организовал зачистку в лесах Кокоревском, Владимирском, Шемякинском и Вороний Лог. Позже там были обнаружены тела свыше тысячи граждан ${ }^{78}$.

Из агентурных источников органов госбезопасности СССР также стало известно, что перед тем, как покинуть Локоть, коллаборационисты и немцы провели операцию по «разгрузке» окружной тюрьмы. В двадцатых числах августа 1943 г. были собраны семьи партизан, выведены за город и расстреляны в противотанковых рвах. В самой тюрьме были убиты и частично взорваны вместе со зданием до 1000 пленных партизан ${ }^{79}$.

Согласно советским источникам, за время оккупации в Локотском округе были расстреляны, повешены и замучены более 10 тыс. человек, в том числе сожжены заживо 203 человека. Личным составом РОНА и полиции было полностью сожжено 24 деревни и 7300 колхозных дворов, разрушено 767 общественных и культурных учреждений (не исключено, что часть построек была уничтожена партизанами и частями наступающей Красной армии; по распространенной практике весь ущерб, нанесенный в ходе боев, приписывался оккупантам и их пособникам). Из одного Брасовского района «на принудительные работы» были угнаны около 7 тысяч человек ${ }^{80}$.

На самом деле, большинство из них были эвакуированы на добровольной основе. Конечно, в ходе послевоенной репатриации многие бывшие граждане автономии предпочитали сообщать чекистам, что они были «угнаны насильно» (при этом маршрут «угона» совпадает с маршрутом передислокации РОНА и гражданских беженцев). В 1945 г. советские власти провели

77 Мюллер Р.-Д. На стороне вермахта. Иностранные пособники Гитлера во время «крестового похода против большевизма» 1940-1945 гг. М., 2012. С. 247. В дневнике министра оккупированных восточных территорий А. Розенберга есть запись от 30 июля 1943 г.: «На Востоке ОКВ просит меня предпринять все возможное для эвакуации около 25000 русских (из района Орла)». См.: Политический дневник Альфреда Розенберга, 1934-1944 гг. M., 2015. С. 382.

78 Христофоров В.С. Коллаборационисты отдельно взятого Локотского округа... С. 199. Так, в Вороновом Логу Городищенский сельсовет № 1 было обнаружено 800 трупов, в противотанковых рвах у села Хутор Холмецкий - 95. В последующем были найдены тела около 2500 человек в районе леса Погребские Дачи. См.: ГАБО. Ф. 6. Оп. 1. Д. 54. Л. 16.

79 Сообщение начальнику ЦШПД при Ставке ВГК, 10 сентября 1943 г. // РГАСПИ. Ф. 69. Оп. 1. Д. 748. Л. 156.

${ }^{80}$ На страже государственной безопасности: Органы ВЧК-КГБ-ФСБ на Орловщине. 90 лет. Орел, 2007. С. 60. 
масштабный опрос граждан, переживших оккупацию. Эти опросные листы оставляют впечатление, что они составлялись с явной оглядкой на советские органы госбезопасности. Некоторые подобные «свидетельства» носят явно курьезный характер. К примеру, уроженка поселка Войков А.Ф. Редина сообщила, что «до угона работала... в качестве колхозницы. Угнана... 6 августа 1943 года... немцами и помогал Луданов Иван Константинович». В Германии угнанные были, по словам Рединой, «проданы помещикам по 18 марок за каждую русскую девушку» ${ }^{81}$. Другая респондентка заявила, что «в Мариенбурге нас... купил помещик по 3 рубля» ${ }^{82}$.

Разняться и показания в отношении тех, кто конкретно осуществлял «угон». Помимо абстрактных «немцев» назывались «полиция Каминского и Процюка», «немецкие жандармы при помощи полицаев командира полка Турлакова Б.Н.», «полицейские, руководимые изменником родины Галкиным Михаилом Григорьевичем» и даже «грузины» и «узбеки» ${ }^{83}$. Лишь одна опрошенная, Мария Ефимовна Туркова-Сорокина заявила, что «выехала добровольно с мужем, командиром батальона полиции РОНА Сорокиным Василием Федоровичем» ${ }^{84}$.

Передислокация частей Каминского и эвакуация беженцев на территорию Белоруссии заранее согласовывались с командованием группы армий «Центр». Еще до прибытия «народников» в Лепель комендант города полковник Шмекель и начальник округа Плюско обратились через витебскую газету «Новый путь» (№ 27 от 19.08.43 г.) к населению: «С целью полного уничтожения бандитов по Лепельскому округу, главнокомандующий германской армией приказал одну русскую освободительную армию переместить для продолжительного размещения в нашем округе... Лепельский округ полностью переходит в подчинение русского командования, которое будет руководить политическими, хозяйственными и военными мероприятиями» ${ }^{85}$

В Белоруссии формирования Каминского были включены в проект по созданию сети «оборонных деревень» (Wehrdörfer). С точки зрения немцев, этот проект являлся опорой оккупационной власти и важной формой ведения борьбы с партизанами. Идея «военных поселений» была положительно воспринята в вермахте. Главная цель сводилась к тому, чтобы, во-первых, выселить из районов «ненадежные элементы», а на их место поселить коллаборантов и лояльных лиц, и, во-вторых, чтобы после создания «военных поселений» объединить их в укрепленные районы, которые с помощью полицейских и охранных частей могли бы поддерживать друг друга. В общей сложности в тылу группы армий «Центр» было создано 60 «военных деревень» ${ }^{86}$.

81 ГАРФ. Ф. 7445. Оп. 19. Д. 43. Л. 38.

82 ГАРФ. Ф. 7445. Оп. 19. Д. 43. Л. 6.

${ }^{83}$ ГАРФ. Ф. 7445. Оп. 19. Д. 43. Л. 7, 21, 57, 91, 111.

${ }^{84}$ ГАРФ. Ф. 7445. ОП. 19. Д. 43. Л. 183.

85 РГАСПИ. Ф. 625. ОП. 1. Д. 45. Л. 311.

86 Мюллер Н. Вермахт и оккупация (1941-1944). М., 1974. С. 271. 
Соединение Каминского, с боями прорвавшееся к Лепелю, находилось в оперативном подчинении у местных охранных войск ${ }^{87}$. За безопасность на этой территории отвечали части 286-й охранной дивизии. Район их ответственности включал в себя такие населенные пункты, как Холопеничи, Чашники, Лепель, Глыбочка, Бешенковичи, Сенно и Христиков ${ }^{88}$. Чтобы взять под контроль районы нового округа, Каминскому пришлось рассредоточить свои силы. Штаб бригады расположился в Лепеле, подразделения в Чашниках, Сенно, Бешенковичах, Камень, Бочейково, Свеча, Черея, Лукомоль и в ряде других деревень, прилегающих к этим населенным пунктам ${ }^{89}$.

Фактически с момента прибытия в Лепель между бойцами РОНА и местным населением сложились не самые лучшие отношения. Как отмечает немецкий специалист К. Герлах, «последователи Каминского представляли собой инородное тело и даже не пытались завоевать симпатии местного населения. Настроение было отрицательным с обеих сторон. План полевой комендатуры № 181 по переселению был уже перекрыт полностью, в результате в сентябре 1943 г. произошел хаотичный захват каминцами жилых помещений в населенных пунктах ${ }^{90}$. С этим выводом согласен и А. Даллин. Он считает, что «выгоняя жителей из своих домов, а также заменив местную администрацию своими людьми, Каминский быстро настроил против себя даже ранее сотрудничавших с немцами представителей коренного населения» ${ }^{91}$.

Еще более негативным отношение к бригаде Каминского стало после проведения экспедиций против партизан. Так, 16 октября 1943 г. началась операция «Хубертус» (Hubertus), имевшая целью освободить дорогу СенноЧашники. Три тысячи локотских беженцев планировалось переселить в район Бешенковичи - Сенно - река Усвайка - Чашники, который подлежал умиротворению. Для проведения зачисток были выделены 2-й, 3-й и 5-й стрелковые полки и гвардейский батальон РОНА. После тяжелых боев подчиненные Каминского 27 октября 1943 г. возвратились в Лепель. За время операции каминцы потеряли 34 человека, а партизаны - 562. Немецкий историк Рольф Михаэлис пишет, что наблюдается «большое расхождение между потерями бригады “народного ополчения” и партизан. Даже если признать эти успехи, достигнутые в ходе боевых действий, все равно возникают вопросы» ${ }^{92}$.

На карательный характер операции «Хубертус» указывает и бывший командир взвода связи РОНА М. Говядов. На допросе он показал: «В октябре

87 Мюллер Р.-Д. Указ. соч. С. 247.

${ }^{88}$ Bandenlage Heeresgebiet Mitte. Stand: 31.8.43. M. 1:1000000; Geheim! Anlage zu Befh. H.Geb. Mitte, Abt. Ic- A2: 1721/43 geh // РГАСПИ. Ф. 625. Оп. 1. Д. 40. Л. 55.

89 РГАСПИ. Ф. 625. Оп. 1. Д. 45. Л. 338.

${ }^{90}$ Gerlach C. Kalkulierte Morde. Die deutsche Wirtschafts- und Vernichtungspolitik in Weißrußland 1941 bis 1944. Hamburg, 1999. S. 1052.

91 Даллин А. Указ. соч. С. 48.

${ }^{92}$ Michaelis R. Russen in der Waffen-SS...S. 33. 
1943 года, после того, как бригада переехала в Лепель, Каминским была организована карательная экспедиция против партизан и их семей в районе Сенно, Бешенковичи и Лепель. Перед походом Каминский издал приказ расстреливать за каждого убитого офицера РОНА 20 заложников, а за каждого убитого рядового - 10 человек, причем в тех деревнях, где будет хотя бы один выстрел по «роновцам», предоставлять право бесконтрольного грабежа и расправ над населением. В результате, когда дивизия находилась на марше и проходила населенные пункты, РОНА, пользуясь этим приказом, чинила зверские расправы над населением и деревни подвергались грабежу» ${ }^{93}$.

В определенной степени на преступления РОНА повлияло недостаточное продовольственное обеспечение. Если в Локте бойцы бригады и члены их семей существовали за счет сельскохозяйственного производства округа, то в Лепеле главным источником снабжения были склады 3-й танковой армии, откуда продовольствие отпускалось исключительно для личного состава соединения. Солдатам и офицерам приходилось делить свой паек с женами и детьми. Бывшие «народники» признавали, что как только появились проблемы со снабжением, Каминский посылал отряды в ближайшие деревни, где проводилось изъятие продуктов. Порою эти акции завершались убийствами. Политика Каминского в тот период, как замечает А. Даллин, сводилась к немедленному возмездию за малейшее нарушение его постановлений. В деревнях то и дело происходили грабежи. Простым крестьянам ничего не оставалось, как бежать в лес. Очевидцы также вспоминали, что в Рожине и Липке (под Лепелем) «народники» загнали местных жителей в церкви, а затем предали их огню. Уцелеть после этой акции удалось немногим $^{94}$.

По словам известного в 1940-х гг. популяризатора белорусского национализма Я. Малецкого, «отряды Каминского вели себя как разбойники: сжигали деревни, грабили, насиловали, и не столько гонялись за партизанами, сколько за домашним скотом и птицей» ${ }^{95}$. Хотя эта оценка не лишена некоторой доли правдивой информации, до конца объективной ее назвать трудно. Каминцы, безусловно, совершали преступления на белорусской земле, но в борьбе с партизанами они действовали весьма результативно. К примеру, в итоговой разведсводке ЦШПД за декабрь 1943 г. отмечалось: «С 10 по 13 декабря немецкие части и до двух полков бригады Каминского при поддержке 70 танков и 21 самолета овладели Березино и дорогой Березино - Докшицы» ${ }^{96}$.

93 Цит. по: Макаров В., Христофоров В. Дети генерала Шмидта. Миф о «Локотской альтернативе» // «Родина» (Москва). 2006. № 10. С. 93.

94 Даллин А. Указ. соч. С. 55.

95 Цит. по: Татаренко А. Недозволенная память: Западная Беларусь в документах и фактах: 1921-1954. СПб., 2006. С. 416.

96 Русский архив: Великая Отечественная. Партизанское движение в годы Великой Отечественной войны 1941-1945 гг.: Документы и материалы. М., 1999. Т. 20 (9). С. 436. 
РОНА постоянно привлекалась к антипартизанским операциям. В январе 1944 г. три полка бригады Каминского действовали совместно с немецкими войсками на южном участке Полоцко-Лепельской партизанской зоны ${ }^{97}$. В этих боях «народники» неплохо себя проявили, так что командование тыла 3-й танковой армии отметило русское соединение, сделав его штурмовым, о чем Каминский не без патетики говорил в своем приказе от 8 февраля 1944 года ${ }^{98}$.

Вместе с тем, отношения командира РОНА с представителями вермахта сильно ухудшились. Причиной всему было неудовлетворительное обеспечение продовольствием и невозможность формировать новые подразделения 99 . Каминский серьезно поссорился с командованием 3-й танковой армии 100. В итоге, обер-бургомистр Лепельского округа установил контакты с руководством СС в Генеральном комиссариате «Вайссрутения», который возглавлял высший фюрер СС и полиции в Центральной России и Белоруссии, группенфюрер СС и генерал-лейтенант полиции Курт фон Готтберг. Уже 23 февраля 1944 г. фон Готтберг подписал приказ № 1 о передислокации подразделений штурмовой бригады на территорию областных комиссариатов «Слоним» и «Новогрудок». Основная часть каминцев прибыла в Дятлов ${ }^{101}$. Генеральный комиссар приказал всю работу проводить через штаб связи, который, как и новый самоуправляющийся округ, подчинялся ему лично. Деятельность Каминского контролировало несколько человек, среди них сотрудник областного комиссариата «Новогрудок» майор охранной полиции Фриц Бушман и начальник штаба связи оберштурмфюрер СС Георг Лоляйт ${ }^{102}$.

Попытки обер-бургомистра вновь создать самостоятельное образование по типу Локотского не встретили понимания. Один из бывших переводчиков, работавших рядом с Готтбергом, вспоминал: «В один из дней обергруппенфюрер СС и генерал полиции фон Готтберг прибыл из Минска в Дятлово к Каминскому. Последний планировал здесь, как и в Локте, устроить русское самоуправление. Фон Готтберг и слышать ничего не хотел о самоуправляемой области. Я был переводчиком при этом разговоре, хотя Каминский неплохо говорил по-немецки. Речь, помимо этого, шла о том, что, кроме советских партизан, в этой области воевала еще польская Армия Крайова. Для немцев все были бандитами, и они требовали от Каминского бороться и против

97 РГАСПИ. Ф. 625. Оп. 1. Д. 40. Л. 133, 137.

98 Приказ № 25 по бригаде РОНА, 8 февраля 1944 г. // «Голос народа» (Лепель). 1944. № 5 (91), 16 февраля (среда), С. 1.

99 См.: Выдержка из приказа Каминского от 15 февраля 1944 г. // Жилянин Я., Поздняков Н., Лузгин В. Без линии фронта. Минск, 1975. С. 268.

100 Даллин А. Указ. соч. С. 54.

101 Quinkert B. Propaganda und Terror in Weißrussland 1941-1944. Die deutsche «geistige» Kriegführung gegen Zivilbevölkerung und Partisanen. Paderborn, 2009. S. 312.

102 Gerlach C. Kalkulierte Morde... S. 1053. 
поляков. Каминский, однако, категорически отказался. Фон Готтберг кричал на него, и я старался смягчить его крепкие выражения. Каминский отвечал точно так же - только бранными русскими словами. Тем не менее, я продолжал переводить. Наконец, в какой-то момент Каминскому удалось договориться о том, чтобы РОНА не воевала против Польши» ${ }^{103}$.

Личный состав бригады Каминского вел на новом месте борьбу с партизанами и осуществлял охрану железной дороги и шоссе Лида - Дятлово - Барановичи ${ }^{104}$. Отношение к местному населению было примерно таким же, как и в Лепеле. Некоторые бывшие каминцы после войны старались не вспоминать о неприятных инцидентах, а больше акцентировали внимание на позитивных сторонах своей деятельности. Белай, в частности, сообщил историку Даллину следующее: «Наши отношения с крестьянами округа были в целом хорошими. Изнасилования и прочие преступления строго карались. Уже в Дятлово двое военнослужащих из взвода охраны штаба ворвались в дом священника и похитили вещи из его подвала; он пожаловался нам, считая, что это сделали партизаны. Военнослужащие были приговорены к расстрелу, но священник просил помиловать их. Один офицер из штабного взвода изнасиловал девочку. Девочка была возницей, предоставленной этому офицеру вместе с телегой и лошадью старшиной волости. Офицер был расстрелян» ${ }^{105}$.

Совершенно другие воспоминания о деятельности бойцов РОНА в Белоруссии сохранились у бывшего заместителя командира полка по политической части, лейтенанта Пальчинского. На одном из допросов он показал: «Нами был задержан партизанский обоз с продовольствием в количестве 40 подвод и доставлен в деревню Ковалевичи, где находился начальник штаба бригады майор Фролов, который приказал расстрелять половину женщин, детей и стариков из состава обоза, а остальные были направлены в штаб бригады, где расстреляны. Утром по приказанию того же Фролова дер. Ковалевичи была окружена солдатами взвода разведки полка и полностью сожжена вместе с населением» ${ }^{106}$.

Еще один бывший коллаборационист, А.И. Катков, во время войны редактировавший несколько русскоязычных пропагандистских изданий, вспоминал: «Его [Каминского. - Примеч. авт.] отряды были махновского типа, но сражались хорошо. Каминский расстреливал на месте. На белорусско-польской

103 Цит. по: Michaelis R. Russen in der Waffen-SS... S. 39-40.

104 РГАСПИ. Ф. 625. Оп. 1. Д. 45. Л. 313.

105 HPSSS. Schedule B, Vol. 11, Case 321... P. 8-9.

106 Сообщение наркома внутренних дел СССР Л.П. Берия И.В. Сталину, В. Молотову, Г.М. Маленкову о ходе борьбы с бандитизмом на территории западных областей БССР // НКВД-МВД СССР в борьбе с бандитизмом и вооруженным националистическим подпольем в Западной Украине, в Западной Белоруссии и Прибалтике (1939-1956). Сборник документов. М., 2008. С. 191. 
границе начался уже чистый бандитизм... У Каминского была репутация бандита. Население его терпеть не могло еще больше, чем немцев» ${ }^{107}$.

Своеобразным итогом деятельности бригады РОНА на оккупированных территориях СССР стало ее использование в апреле-мае 1944 г. в крупномасштабной антипартизанской операции «Весенний праздник» (Frühlingsfest). К операции было привлечено 40 процентов личного состава соединения. Причем в боевом приказе (11 апреля 1944 г.) бригада Каминского была обозначена как эсэсовское формирование ${ }^{108}$, хотя официальное включение «народников» в СС последовало несколько позже - 17 июня $^{109}$.

На время операции, как уже неоднократно бывало, Каминскому придали оперативную команду СД ${ }^{110}$. Кроме того, бригада получила приказ выделить подразделение для транспортировки пленных, рабочей силы и сельскохозяйственных продуктов. Захваченное население необходимо было свозить в сборный пункт Драчево (был рассчитан на 1200 человек) ${ }^{111}$. Затем гражданских лиц следовало передать в лагеря 3-й танковой армии: в Парафьяново (дулаг № 230), в Глубокое (сборно-пересыльный пункт № 8) и в Боровню (усиленный опорный пункт на шоссе Лепель - Камень) ${ }^{112}$. Этот алгоритм действий, тщательно прописанный в приложениях к боевому приказу, был тесно связан с фильтрационными мероприятиями, которые изначально подразумевали под собой целый комплекс репрессивных мер в отношении лояльного партизанам населения.

Айнзатцгруппа Каминского действовала весьма успешно, что отметил даже фон Готтберг. В отчете о проведении операции «Весенний праздник» он, в том числе, подчеркнул: «Оперативной группе Каминского удалось после тяжелых боев прорваться через южные рубежи обороны противника и взять его позиции штурмом... Пленные показали, что группа Каминского, а также правое крыло группы «Ангальт» уничтожили, по меньшей мере, 2000 человек из бригад Родионова и Алексеева» ${ }^{113}$.

В мае 1944 г. оставшиеся части соединения Каминского были переброшены в район Дятлова. Перед тем, как покинуть Лепель, была проведена

107 HPSSS. Schedule B, Vol. 4, Case 384. 17-18.01.1951. P. 5-6.

108 Kampfgruppe von Gottberg, Einsatzbefehl, 11.4.44 // NARA, T-354, Roll 650.

109 Michaelis R. Russen in der Waffen-SS...S. 43. Согласно партизанским донесениям, еще весной 1944 г. Готтберг от имени Гиммлера предложил Каминскому перейти в состав СС. См.: РГАСПИ. Ф. 625. Оп. 1. Д. 45. Л. 835.

110 Der Befehlshaber der Sicherheitspolizei und des SD Rußland-Mitte und Weißruthenien, Sonderbefehl, 10.4.1944 // NARA, T-354, Roll 650.

111 Anlage 2 zum Einsatzbefehl des Unternehmens «Frühlingsfest», Tgb. Nr. I a geh. Nr. 520 v. 11.4.1944 // NARA, T-354, Roll 650.

112 Anlage 2a zum Einsatzbefehl des Unternehmens «Frühlingsfest», Ia Tgb. Nr. 520/44 geh. vom 11.4.44 // NARA, T-354, Roll 650.

113 Kampfgruppe von Gottberg, Gefechtsbericht zum Unternehmen «Frühlingsfest», 12.05.44 // NARA, T-311, R. 218. F. 000846-000847. 
зачистка города и его тюрьмы. Пальчинский вспоминал: «При эвакуации штаба бригады Каминского из Лепеля в Дятловский район Барановичской области от штаба бригады был получен приказ о взрыве Лепельской тюрьмы, где находилось около 1000 арестованных, и сожжении гор. Лепель. Этот приказ нами был полностью выполнен» ${ }^{114}$.

Надо сказать, что в период нахождения РОНА в Лепеле, согласно многочисленным свидетельским показаниям, военнослужащие и чиновники автономии подтвердили свою жестокую репутацию. Уроженка Лепеля Н.К. Тухто вспоминала, что советских патриотов расстреливали «сообщники немцев, солдаты из банды Каминского. Сидя в... тюрьме, я сама вынесла очень много издевательств на допросах. Били, чем попало: плетьми, палками, шомполами, и так, избитую, опять бросали в грязную камеру» ${ }^{115}$. Другая местная жительница Е. Сыса показала: «Мне известны зверские издевательства над гражданином Полянского с/с [сельсовета. - Примеч. aвm.], которого бандит Каминский и Працук своими сапогами на смерть убили 6/V44 г. и выбросили на улицу, мотивируя тем, что не вовремя представил для них подводы» ${ }^{116}$.

После того, как бригада РОНА прибыла в новый округ, в окрестностях Дятлова проводились постоянные операции по прочесыванию местности. Если верить показаниями И.Д. Фролова, командовавшего 1-м полком, эти акции не дали большого эффекта, так как партизаны заранее ушли из района, где намечалось прочесывание ${ }^{117}$. Во второй половине мая 1944 г., когда бригада вела бои против партизан Липичанской пущи, в деревнях Корытница, Великая Воля и Демьяновичи было «сожжено много жилых домов и ограблено все население» ${ }^{118}$.

В начале июля 1944 г., когда советские войска вошли в Барановичскую область, РОНА удерживала западный край Налибокской пущи и 4 июля вступила в бой с партизанами у Негневичей. А 8 июля соединение было введено в бой против наступающих частей Красной Армии и вместе с 50-й пехотной дивизией пыталось удержать линию Вселюб - Новогрудок. В этих боях бригада понесла тяжелые потери ${ }^{119}$. В один из дней соединение оказалось в окружении, но, как показал после войны генерал

114 Сообщение наркома внутренних дел СССР Л.П. Берия И.В. Сталину, В. Молотову, Г.М. Маленкову... С. 191-192.

115 ГАРФ. Ф. Р-7021. Оп. 84. Д. 7. Л. 91.

116 ГАРФ. Ф. Р-7021. Оп. 84. Д. 7. Л. 95.

11710 июня 1946, лагерь № 256. Из протокола допроса командира сводного полка бригады РОНА И. Фролова // Варшавское восстание... С. 630.

118 Сообщение наркома внутренних дел СССР Л.П. Берия И.В. Сталину, В. Молотову, Г.М. Маленкову... С. 192.

119 Michaelis R. Russen in der Waffen-SS...S. 45. На этом участке фронта вели бои боевая группа фон Готтберга, боевая группа генерал-лейтенанта Флерке, группа заграждения генерала Вейдлинга. См.: Hinze R. Ostfront 1944. Suttgart, 2011. S. 433. 
СС Эрих фон дем Бах, подчиненные Каминского сумели пробиться «через русское кольцо» ${ }^{120}$.

Дальнейшая история формирования Каминского была связана с печально известным Варшавским восстанием 1944 г. Сводный полк РОНА занимался в польской столице массовым истреблением населения, грабежами, пьянством и насилием. Куча разложившихся наемников распоясалась настолько, что стала насиловать и убивать немецких женщин. В результате, согласно наиболее распространенной версии, Каминский был вызван в штаб руководителя операции и расстрелян во внесудебном порядке ${ }^{121}$.

\section{Русская автономия и "еврейский вопрос»}

Карательную деятельность формирований Каминского, безусловно, невозможно рассматривать в отрыве от геноцида еврейского населения на оккупированной территории СССР. В захваченных районах Орловской области мероприятия против евреев начались еще в конце лета 1941 г. В частности, 25 августа в поселке Злынка было расстреляно 27 человек. В дальнейшем истребительные акции были проведены в таких населенных пунктах, как Клинцы, Унеча, Новозыбков, Стародуб, Трубчевск, Почеп и Клетня ${ }^{122}$.

Осенью 1941 г. на Брянщине появились гетто, куда оккупационные власти собирали евреев, прежде чем их уничтожить. Гетто появились в Злынке, Клинцах, Унече, Карачеве, Стародубе, Клетне и Мглине. По самым приблизительным подсчетам, в них содержалось около 5 тысяч узников ${ }^{123}$. В тыловом районе группы армий «Центр» гетто существовали сравнительно недолго. Так, в восточных областях Белоруссии, попавших в сферу деятельности военной администрации, почти все гетто прекратили свое существование с осени 1941 г. по весну 1942 г. Аналогичная картина была в северо-западных и центральных областях РСФСР. Именно в этот период оперативные команды СД, части полиции порядка и войск СС проводили самые крупные расправы над евреями ${ }^{124}$.

120 Алексеев В.М. Варшавское восстание. Варшава в борьбе против гитлеровских захватчиков. СПб., 1999. С. 101.

121 Klausch H.-P. Antifaschisten in SS-Uniform. Schicksal und Widerstand der deutschen politischen KZ-Häftlinge, Zuchthaus- und Wehrmachtsgefangenen in der SS-Sonderformation Dirlewanger. Bremen, 1993. S. 106.

122 Альтман И.А. Жертвы ненависти. М., 2002. С. 262-263.

123 Брянская область // Холокост на территории СССР: Энциклопедия. М., 2009. С. 115.

124 Розенблат Е.С. Холокост и антифашистское еврейское сопротивление на белорусской земле // Беларусь 1941-1945: Подвиг. Трагедия. Память. В 2 кн. Кн. 1. Минск, 2010. С. 218. Более подробнее об уничтожении евреев на Брянщине в годы войны см.: Stopper S. Op. cit. S. $40-47$. 
К тому моменту, когда летом 1942 г. официально появился Локотский округ, «еврейский вопрос» в регионе был во многом решен. В районах, входивших в состав самоуправления, оставалось не так уж и много евреев. В основном это были люди, чудом пережившие первую волну уничтожения. Никто из них особо не афишировал свою национальность, так как антисемитский характер администрации Каминского, его полицейских органов и вооруженных отрядов был хорошо известен.

Антиеврейская риторика локотских коллаборационистов проявилась с самого начала их правления. В опубликованном манифесте Народной социалистической партии России (25 ноября 1941 г.) был пункт 12, который гласил: «Беспощадное уничтожение евреев, бывших комиссарами» ${ }^{125}$. Даллин, проанализировавший этот документ, полагает, что данный пункт был включен в программу НСПР с «оглядкой на немецкие оккупационные власти». По его мнению, эта сентенция сильно контрастирует с другими пунктами программы и выглядит на общем фоне весьма нелогично ${ }^{126}$.

Действительно, появление в манифесте призыва «уничтожать евреев, бывших комиссарами» связано с влиянием немецкой антисемитской пропаганды. В данном случае, в основу 12-го пункта был положен - в несколько измененном виде - знаменитый «кирпичный лозунг» («Бей жида-политрука, рожа просит кирпича!») ${ }^{127}$. Появление этого пункта, вопреки заявлению Даллина, выглядит вполне логичным, просто руководители НСПР не сумели четко сформулировать свою позицию по «еврейскому вопросу». Причем, если бы этот пункт не имел никакого значения, то тогда бы в печатных органах автономии антисемитская тема не поднималась. Но история Локотского округа свидетельствует о том, что антисемитизм для местных коллаборационистов не был пустым звуком.

Периодические издания самоуправления постоянно демонстрировали свою приверженность антиеврейской линии. Газета «Голос народа», например, поставила перед собой задачу возбудить «всеобщую ненависть к жидо-большевизму и его союзникам - англо-американским плутократам», а также приравнивала обычный физический труд к вооруженной борьбе против «жидо-большевистской власти» ${ }^{128}$.

Едва ли не в каждом номере газеты встречались антисемитские конструкции «жидо-большевики», «иудо-большевизм», «жидо-комиссары»

125 Дробязко С.И. Локотский автономный округ и Русская Освободительная Народная Армия // Материалы по истории Русского Освободительного Движения: сборник статей, документов и материалов. Вып. 2. М., 1998. С. 173.

126 Даллин А. Указ. соч. С. 18.

127 Подробнее см.: Жуков Д.А., Ковтун И.И. Антисемитская пропаганда на оккупированных территориях РСФСР, 1941-1944 гг. Ростов-на-Дону, 2015. С. 90.

128 Черняков Д.И. Локотская газета «Голос народа» на службе у нацистской пропаганды. 1942-1943 гг. // «Вопросы истории» (Москва), 2010. № 5. С. 65, 67. 
и т.п. Рядом с «шапкой» газеты иногда появлялись лозунги типа «Никогда больше ни жид, ни коммунист не смогут повергнуть Нашу Родину в кровавый ужас жидовского гнета и террора» ${ }^{129}$. В статье, посвященной 44-летию Каминского, в числе основных добродетелей обер-бургомистра был назван его антисемитизм ${ }^{130}$. Точно так же характеризовали Каминского и свидетели, считавшие его «ярко выраженным антисемитом» ${ }^{131}$.

В Локотском районе был установлен порядок, согласно которому расстрелу подлежали лица, укрывавшие коммунистов и евреев ${ }^{132}$. В законодательстве округа присутствовали явные антисемитские положения. В «Трудовом кодексе» существовал специальный параграф под названием «Жидовская рабочая сила». В инструкции, подготовленной отделом юстиции, запрещались браки между евреями и лицами других национальностей (документ позволял в считанные минуты оформить развод с евреем, даже по одностороннему желанию одного из супругов $)^{133}$. Регистрация браков между евреями и неевреями была категорически запрещена ${ }^{134}$.

После того, как в августе 1943 г. РОНА была передислоцирована в белорусский Лепель, Каминский продолжил свою антисемитскую политику. Витебская газета «Новый путь» в очерке, посвященном Лепельскому самоуправлению, к примеру, писала: «При назначении работника на ту или иную должность принимается в расчет только одно условие - его деловые качества. Что же касается социального, национального (евреям места нет), партийного и т.д. положения, то последнее роли не играет» ${ }^{135}$.

8 декабря 1943 г. была образована Национал-социалистическая трудовая партия России (НСТПР), которую специалисты рассматривают как русский аналог НСДАП ${ }^{136}$. Представители партии вели исключительно интенсивную пропагандистскую работу среди белорусского населения, не ограничиваясь только территорией Лепельского округа. В своей деятельности они использовали антисемитскую риторику. Так, во время своего выступления в Полоцке председатель окружного комитета Пономарев произнес следующие слова:

129 См.: «Голос народа» (Локоть). 1942. № 37, 20 декабря (воскресенье). С. 1.

130 Христофоров В.С. Коллаборационисты отдельно взятого Локотского округа... С. 183.

131 Из письма Л. Потаповой Николаевскому, 28 декабря 1949 г. // Под немцами... С. 502.

132 Анищенко Е. Партизанская республика. Героические повествования о народных мстителях Навлинского района Брянщины. Тула, 1992. С. 18.

133 Ермолов И.Г. Русское государство в немецком тылу. История Локотского самоуправления. 1941-1943. М., 2009. С. 62.

134 Инструкция Бутеровской волости о производстве записей актов гражданского состояния по Локотскому округу, 1942 г. // РГАСПИ. Ф. 69. Оп. 1. Д. 1143. Л. 113.

135 О Лепельском самоуправлении // «Новый путь» (Витебск). 1944. № 28 (273), 6 апреля. С. 2.

136 Гребень Е. Русская национальная идея как элемент террора коллаборационистских властей // Нацистская война на уничтожение на северо-западе СССР: региональный аспект. Материалы международной научной конференции (Псков, 10-11 декабря 2009 года). M., 2010. C. 95. 
«Да здравствует союз национальной России и национальной Германии! Долой Сталина, жидов и компартию!» ${ }^{137}$.

В выступлениях самого Каминского звучали антисемитские выражения. Обер-бургомистр так определил цели, во имя которых ведет борьбу его бригада: «Мы боремся против закабаления нашей родины большевистской системой, за истинную свободу и равноправие народов России. Мы боремся против еврейской нации, за свободный от колхозного рабства и государственного капитализма труд» ${ }^{138}$.

Историк К.М. Александров, автор комментариев к сборнику «Под немцами», почему-то считает, что на территории Локотского округа «антисемитская риторика... вступала в противоречие с практикой». Данное утверждение абсолютно не соответствует действительности и, ко всему прочему, намеренно формирует ложное представление об отношении к «еврейскому вопросу» в автономии. Исследователь не привел убедительных доказательств в пользу своей версии, ограничившись лишь ссылкой на свидетельство бывшей жительницы округа, беженки Л. Потаповой, которая при этом предупреждает, что располагает «данными только в диаметре три километра, так как на большее расстояние» она «не имела права передвигаться». Потапова, кроме того, признает, что 30 евреев, «державшихся особняком», были «сгруппированы в гетто» ${ }^{139}$.

На самом деле, антисемитская риторика коллаборационистов не отступала от их практических мероприятий. Расстрелы евреев проводились в Севском и Суземском районах округа. В последнем случае экзекуциями руководил начальник районной полиции Прудников. В районе были убиты 223 еврея $^{140}$.

137 Митинг членов НСТПР в г. Полоцк // «Русское дело» (Белград). 1944. № 27, 27 мая (суббота). С. 2.

138 Данченко. Русское воинство // «Руль» (Барановичи). 1944. № 116, 17 марта (пятница). С. 3.

139 Под немцами... С. 502. Историк также продолжает придерживаться ложного тезиса, введенного в оборот Б.И. Николаевским, который не видел в Каминском национал-социалиста. См.: Александров К.М. К вопросу об историографии вооруженных формирований Локотского ополчения и русского самоуправления в юго-западных районах Орловской области в 1941-1943 гг. // «Новый часовой» (Санкт-Петербург). 2011. № 19-20. С. 289. По словам Э. фон дем Бах-Зелевски, Каминский «был русским националистом. Можно сказать, что его идеология была чем-то вроде русского нацизма». См.: Алексеев B.M. Варшавское восстание... С. 102. Ту же самую точку зрения разделяет западногерманский специалист Э. Хессе: «Политические взгляды Каминского, особенно на внутриполитические проблемы, были схожи с воззрениями национал-социалистов в Германии». См.: Hesse E. Der sowjetrussische Partisanenkrieg 1941 bis 1944 im Spigel deutscher Kampfweisungen und Befehle. Göttingen, 1969. S. 176. Эту же позицию в определенной мере поддерживает известный немецкий исследователь К. Герлах: «Каминский представлял русско-националистическую идеологию с отчетливой фашистской тенденцией». См.: Gerlach C. Kalkulierte Morde... S. 1052.

140 Альтман И.А. Указ. соч. С. 263. 
Самый известный случай уничтожения евреев в Локотском округе связан с ликвидацией гетто в Навле. В июле 1942 г. ЦШПД дал задание Брянскому штабу партизанского движения осуществить взрыв железнодорожного моста через р. Навля на линии Брянск - Льгов с целью срыва перевозок живой силы и техники вермахта на этой стратегически важной магистрали. Штаб навлинских партизанских отрядов принял решение захватить мост боем и взорвать его. Операция прошла удачно, и мост был взорван в августе 1942 г. ${ }^{141}$ По другой версии, подпольщики и партизаны изначально планировали организовать в Навле восстание, но каминцы опередили «народных мстителей» и арестовали большую часть подпольщиков. В этих условиях партизаны не рискнули штурмовать районный центр и ограничились подрывом моста $^{142}$. В любом случае, в отместку за эту акцию полицейские Навли во главе с Н. Скакодубом-Наконечным расстреляли всех евреев из местного гетто (36 человек) ${ }^{143}$.

Органами НКВД также было установлено, что все евреи, проживавшие в Дмитриеве Курской области, были согнаны на окраину города и поселены в нескольких домах. В соответствии с указаниями руководителей автономии их направляли на разминирование дорог и полей, при этом многие из узников Дмитриевского гетто погибли. При отступлении подразделений Каминского из города все уцелевшие евреи были расстреляны ${ }^{144}$.

В рамках борьбы с партизанами Каминским проводилась работа по очернению советской власти и созданию условий для морального разложения партизанских отрядов. Для этого использовались антисемитские конструкции. К примеру, в одном из обращений к партизанам и сочувствовавшему им населению обер-бургомистр заявил: «Германские части сейчас находятся на подступах к Царицыну. Кавказ и Кубань уже отрезаны от центральной части России. Народ за жидов и коммунистов воевать не хочет... В неосвобожденных от жидовского ига областях России наблюдаются массовые выступления против режима Сталина; голод стоит невероятнейший. Вас же жидовские комиссары убаюкивают близким фронтом и мнимыми победами Красной армии» ${ }^{145}$.

Со слов некоторых бывших членов РОНА, в «армии Каминского» якобы не существовало никакого «сугубого антисемитизма», а личный состав бригады захваченных в лесу евреев немцам не отдавал ${ }^{146}$. Эти и подобные им

141 Пономаренко П.К. Всенародная борьба в тылу немецко-фашистских захватчиков 1941-1944. М., 1986. С. 202-203.

142 См. подробнее: Анищенко Е.Н. Через толщу лет. Документальные очерки о партизанах и подпольщиках Брянщины. Тула, 1996. С. 31-50.

143 Жуков Д.А., Ковтун И.И. 29-я гренадерская дивизия СС... С. 73.

144 Христоборов В.С. Коллаборационисты отдельно взятого Локотского округа... С. 183.

145 Обращение // «Голос народа» (Локоть), 1942. № 14, 5 августа. С. 3.

146 Даллин А. Указ. соч. С. 72. 
сентенции, зафиксированные Даллиным, вызывают большие сомнения, поскольку они звучали из уст людей, стремившихся после войны представить себя в благоприятном свете. Одним из немногих, кто попытался сказать некоторую правду, был Белай: «Множество евреев скрывалось в партизанских отрядах, когда мы захватывали их в плен, отношение к ним было, как правило, таким же, как и к остальным партизанам» ${ }^{147}$. Говоря иначе, их ждала смертная казнь или заключение в тюрьму, откуда немногие выходили живыми.

В целом необходимо отметить, что в Локотском (а затем в Лепельском) округе антисемитизм вовсе не представлял собой оторванную от реалий оккупационного бытия форму национальной нетерпимости. Деятельность в этом направлении не ограничивалась публикацией юдофобских статей и обращений, но также проявляла себя в конкретных карательных акциях против евреев. Даже тогда, когда «еврейский вопрос» в автономии был де-факто решен, ненависть к евреям продолжали разжигать через периодические издания самоуправления. Немецкий историк Д. Поль связывает действия такого рода со специально культивируемым чувством страха перед возвращением большевиков $^{148}$. Думается, эта позиция отчасти объясняет, почему антисемитские лозунги сопровождали бригаду РОНА на всем пути ее существования. Также невозможно, учитывая идейный характер сторонников Каминского, исключать у них антиеврейские взгляды ${ }^{149}$.

\section{Децимация неверных}

С момента образования Локотского самоуправления его руководители всегда стремились привлечь на свою сторону гражданское население. Для достижения этой цели коллаборационисты использовали все имевшиеся средства, начиная от пропаганды, принятия законов, направленных на изменение жизни местных жителей, и заканчивая обеспечением безопасности на той территории, в границах которой им было позволено проявлять свою самостоятельность. Политические воззрения представителей автономии, отличавшиеся крайне резким неприятием советской власти, оказывали

147 HPSSS. Schedule B, Vol. 11, Case 321... P. 11.

148 Pohl D. Op. cit. S. 255.

149 Верхом некомпетентности следует признать размышления по этому вопросу журналиста С. Веревкина, отрицающего существование антисемитизма в Локотском округе. Автор, кроме того, пускается в совершенно нелепые рассуждения о судьбе переводчика А.Б. Вронского-Блюма, сознательно искажая факты, связанные с его арестом и казнью. Хотя историки С. Дробязко и И. Ермолов однозначно квалифицируют эти действия, как одно из проявлений антисемитской политики окружной администрации. См.: Веревкин С.И. Самая запретная книга о Второй мировой... С. 196-213. 
серьезное влияние на содержание принимаемых решений. Поэтому борьба с теми, кто не хотел жить по установленным здесь правилам, довольно часто носила радикальный характер. В этом нет ничего удивительного, поскольку условия, в которых проводился локотский эксперимент, трудно назвать нормальными.

Кроме того, на радикализацию отношений между жителями автономии оказывала сильное воздействие личность Бронислава Каминского. Он сам формировал удобную для себя среду обитания и одновременно распространял ее на своих приближенных и «подданных». Выпасть из этой среды означало не только стать противником «нового порядка», но и личным врагом обер-бургомистра, который жестоко расправлялся с мятежниками и «отступниками».

Один из первых случаев, когда в отрядах Каминского произошло разложение и переход на советскую сторону, относится к весне 1942 г. В марте за связь с партизанами был расстрелян старшина Шаровской волости Комаричского района. 20 апреля четверо бойцов из гарнизона Хутора Холмецкого перебежали к «народным мстителям». 22 апреля свой пост на железнодорожном мосту покинул боец Святовского отряда, который, однако, был схвачен и расстрелян. В приказе № 118 (от 25 апреля 1942 г.) Каминский упоминал об этих фактах, и связывал подобные действия с проявлением «открытого предательства», «паники и трусости» ${ }^{150}$.

Однако вскоре командиру народной милиции пришлось столкнуться с куда более серьезными проблемами. 29 апреля 1942 г. партизанам удалось временно захватить деревни Тарасовка и Шемякино ${ }^{151}$. Захват населенных пунктов стал возможен благодаря подпольной работе старосты деревни Шемякино Машурова и группы полицейских Гапеенкова ${ }^{152}$. Значительная часть стражей порядка влилась в партизанские отряды, ликвидировав ротных командиров. В общей сложности в руки партизан попали 150 человек, из которых 57 были расстреляны за активную деятельность в пользу оккупантов $^{153}$. По утверждению пропаганды каминцев, «партизаны замучили и расстреляли 115 человек местных жителей, в том числе много женщин и детей, причем половина этих жертв была подвергнута мукам и издевательствам» ${ }^{154}$.

150 Макаров В., Христоборов В. Указ. соч. С. 90.

151 В журнале дежурного офицера штаба коменданта тылового района 2-й танковой армии есть запись от 29.04.42 г.: «Каминский докладывает из Локтя: Тарасовка и Шемякино (14 км западнее Локтя), благодаря предательству, заняты сегодня ночью противником. Гарнизон взят в плен. Угроза Локтю. Для усиления милиции посланы 2 роты железнодорожных войск 2-й танковой армии». См.: Под немцами...С. 479.

152 Забельский М.А. На «малой» земле // Незримого фронта солдаты. Сборник воспоминаний. Тула, 1971. С. 265; Гаврилкин Г.А. Непокоренный суземский край (Хроника партизанской битвы) // Поклонимся великим тем годам... Москва-Суземка, 2005. С. 31.

153 Морозов В.К. Врагу от нас не уйти // За линией фронта. Очерки. Тула, 1968. С. 137; Партизаны Брянщины. Сборник документов и материалов. Т. 2. Брянск, 1962. С. 128.

154 Цит. по: Соколов Б.В. Указ. Соч. С. 178 
В течение всей первой декады мая 1942 г. отряды Каминского при поддержке немецкой авиации вели ожесточенные бои за Тарасовку и Шемякино. Наконец, 11 мая «народникам» удалось сломить сопротивление партизан и вернуть населенные пункты под свой контроль. В плен попал командир Кокоревского партизанского отряда В.В. Чечерин, который был приговорен военно-полевым судом к смертной казни. Приговор привел в исполнение командир бронедивизиона Ю.Ф. Самсонов, отрубивший партизану голову саблей.

В. Христофоров полагает, что каминцы устроили массовую казнь местных жителей (всего 150 человек). После занятия деревень последовала расправа над семьями бывших полицейских. Автор ссылается при этом на протокол послевоенного допроса бывшего командира взвода связи РОНА, М. Говядова, хотя сам Говядов в Тарасовке и Шемякино не был. Не исключено, что он озвучивал то, что хотели услышать следователи. Большой вопрос вызывает совпадение числа «150» в обоих случаях (29 апреля и 11 мая) ${ }^{155}$. Кроме того о расправе со стороны каминцев ничего не пишут в своих воспоминаниях непосредственные участники событий, чекисты В. Засухин и М. Забельский.

Летом и осенью 1942 г., когда каминцы вели постоянные бои с брянскими партизанами, отмечались случаи бегства из рядов полиции. Так, в августе 1942 г. из Локтя ушли 35 стражей порядка, которых приняли в бригаду «За власть Советов» ${ }^{156}$.

Каминский страшно не любил, когда кто-либо из его подчиненных проявлял трусость в бою, уклонялся от огневых контактов с партизанами или просто дезертировал. В этих случаях командир бригады действовал сурово. К примеру, при штурме деревни Ольговка Комаричского района четверо бойцов «народной милиции» бежали с поля боя. Обер-бургомистр лично командовал их расстрелом перед строем ${ }^{157}$.

Для поддержания дисциплины Каминский использовал все доступные ему средства - от хитрости до жестокости. Он отправлял провинившихся на гауптвахту или помещал их в особую камеру в Локотской тюрьме. Если же проступок имел тяжелые последствия для подразделения, то виновного приговаривали к смертной казни. Этот аспект «воинского воспитания» в частях Каминского вряд ли мог вызывать у личного состава положительную реакцию. Жестокие наказания обычных солдат, скорее, формировали внутри подразделений негативную моральную атмосферу, чем пользовались в своих целях подпольщики и партизаны.

Надо сказать, что советское подполье активно внедряло своих агентов в ряды «народной милиции» и РОНА. Однако спланированные

155 Христофоров В.С. Коллаборационисты отдельно взятого Локотского округа... С. 196-197.

156 Черняков Д.И. «Все евреи, в том числе и маленькие дети... расстреляны». Полицейские формирования Брянщины на службе у гитлеровских захватчиков $(1941$ - 1943 гг.) // «Военно-исторический журнал». 2011. № 5 (613). С. 18.

157 Татаренко А. Указ. соч. С. 406. 
подпольщиками операции по переходу каминцев на сторону партизан поначалу терпели крах. Например, была полностью разгромлена организация в навлинском вооруженном отряде. Практически все ее члены были арестованы полицией. К уголовной ответственности были привлечены несколько десятков человек, большинство из которых было расстреляны ${ }^{158}$. Такая же судьба постигла подпольщиков из Комаричей во главе с П.Г. Незымаевым, казненных по приговору военно-полевого суда ${ }^{159}$.

До определенного момента Каминскому удавалось железной рукой наводить порядок в батальонах и пресекать попытки разложения милиции. Однако с приближением фронта к границам округа ситуация стала меняться. Фиксировалось все больше случаев перехода бойцов РОНА к партизанам. Так, в отчете полиции безопасности и СД за вторую половину января 1943 г. говорилось: «Во время проверки батальона "Народной стражи” в самоуправляющемся округе Локоть командир этого батальона и его адъютант отдали приказ о расстреле командира 1-й роты, так как последний способствовал переходу подразделения к бандам. На следующий день, однако, большая часть людей вернулась. К бандам ушло примерно 35 человек с 25 винтовками и 5 пулеметами. Инцидент произошел в то время, когда руководитель самоуправляющегося округа Локоть, Каминский, принимал участие в борьбе с бандами [имеется в виду операция «Белый медведь». - Примеч. авт.]. В ночь на 17.1. произошло нападение бандитов на Шарово (16 км южнее Локоть), которое было отбито. Дезертировавшие ранее члены батальона "Народной стражи" принимали участие в этом нападении» ${ }^{160}$.

В том же месяце из комаричского отряда милиции бежали 59 человек, примкнувших к отряду им. Чапаева, а в феврале - дезертировали 150 бойцов ${ }^{161}$. Особенно много переходов пришлось на февраль 1943 г., когда на территории округа развернулись бои между вермахтом и наступающими частями Красной Армии. В одном из спецсоощений чекистов, работавших в партизанских бригадах Брянщины, отмечалось: «В результате комплекса мероприятий, проведенных органами НКВД в бригаде Каминского, зимой 1943 г. на сторону партизан и Красной Армии перешло свыше 1000 человек» ${ }^{162}$.

158 См. подробнее: Анищенко Е.Н. Через толщу лет... С. 31-50.

159 См.: Приговор Военно-полевого суда Локотского округа // Грибков И.В. Хозяин Брянских лесов. Бронислав Каминский, Русская освободительная народная армия и Локотское окружное самоуправление. М, 2008. С. 113.

160 Tätigkeits- und Lagebericht Einsatzgruppe B für die Zeit vom 16.-31.1.1943 // Mallmann K.-M., Angrick A., Matthäus J., Cüppers M. ...Bd. II. S. 513.

161 Краткий очерк о партизанском движении в Комаричском районе (октябрь 1941 г. - апрель 1943 г.) // Личный архив И.И. Ковтуна. Л. 24.

162 Из спецсообщения начальника Особого отдела НКВД объединенных партизанских бригад... // Органы государственной безопасности СССР... Т. IV. Кн. 1. М., 2008. С. 248. 
Насколько достоверны эти данные, однозначно сказать трудно, однако атмосфера разложения в батальонах милиции присутствовала. Об этом позже рассказали на допросе перебежчики: «Подавляющее большинство бойцов бригады, а также часть командиров, призванных в бригаду Каминского по мобилизации, не верили в окончательную победу немцев, несмотря на жестокие репрессии по отношению к убежавшим из бригады и их семьям, со стороны командования, в бригаде имели место случаи одиночного, а также группового перехода к партизанам» ${ }^{163}$.

В то же время борьба с подпольными организациями внутри РОНА продолжалась, и порой очень успешно. В отчете полиции безопасности и СД за март 1943 г. сообщалось: «В Локте раскрыто разветвленное движение сопротивления, которое поддерживало связь с бандитской бригадой “За Родину” и имело задачу с помощью шпионажа, саботажа и террористических актов подготовить переворот в Локте. С этой целью шесть русских должны были устранить его должностных руководителей, обер-бургомистра Локтя и его заместителя. В дальнейшем мятежники хотели убить немецких офицеров и солдат, кроме того, довести до хаотичного состояния “Народную стражу" и использовать ее на своей стороне. Пока было арестовано 40 заговорщиков, которые частично проживали в Локте и частично в районе Брасово» ${ }^{164}$.

Как сегодня установлено, речь шла об антифашистской организации Брасовского района. Возглавлял ее начальник мобилизационного отдела автономии С.В. Васильев. Пользуясь своим служебным положением, он разъезжал по округу и занимался вербовкой новых членов. В марте 1943 г. организацию раскрыли. За несколько дней контрразведка Каминского и сотрудники абвергруппы-107 арестовали практически всех участников подполья. Перебежчики из бригады показали на допросе: «В бригаде стали возникать подпольные партизанские отряды, таким был, например, отряд Васильева, который вовлек в свой отряд до 150 человек каминцев. Отряд имел связь с партизанским отрядом “Смерть немецким оккупантам". Захваченный полицией Каминского партизан отряда "Смерть немецким оккупантам" Поздняков, под действием пыток, сообщил Каминскому о существовании в бригаде подпольного партизанского отряда, имевшего тесную связь с партизанами. Отряд во главе с Васильевым заключен в тюрьму. Попытку организации партизанского отряда также предпринял и начальник штаба гвардейского батальона старший лейтенант Бабич, который во время вербовки в отряд новых лиц был предан и при попытке побега был тяжело ранен и схвачен начальником военной коллегии Працюком. Завербованные Бабичем

163 РГАСПИ. Ф. 69. Оп. 1. Д. 750. Л. 108.

164 Tätigkeits- und Lagebericht Einsatzgruppe B für die Zeit vom 1.-31.3.1943 // Mallmann K.-M., Angrick A., Matthäus J., Cüppers M... Bd. II. S. 573. 
в отряд были частично схвачены и посажены в тюрьму, большинство бежало в лес. Организованные внутри бригады подпольные отряды партизан ставили первой задачей - убийство Каминского и его ближайших пособников. Роспуск бригады» ${ }^{165}$.

По свидетельству Белая, Каминский приказал схватить около 100 человек. Многие из них были приговорены к смерти. Белай вспоминал о том, что Каминский помиловал семью Васильева, а затем и самого главного заговорщика освободили, перевербовали и направили на обучение в разведшколу в Минске. После ее окончания Васильев вернулся в бригаду, которая к тому времени дислоцировалась в Дятлово. В период отступления немецких войск из Белоруссии Васильев был оставлен с разведывательным заданием в Минске, где позже был арестован и повешен советскими властями ${ }^{166}$.

В воспоминаниях бывшего командира бригады «За Родину» А. Малышева, бывшего заместителя командира бригады по разведке М. Ковалева и бывшего политрука отряда «За Родину» В. Цыганкова говорится: «В течение 2-3 дней марта 1943 года гестапо с помощью провокаторов арестовало около 80 коммунистов, комсомольцев и членов антифашистских групп [по другим сведениям было арестовано около 200 человек, включая, видимо, членов семей подпольщиков. - Примеч. авт ${ }^{167}$.]. Большинство из них было расстреляно или повешено. Это было тяжелой утратой для бригады» ${ }^{168}$.

Несмотря на разгром организации, остановить бегство бойцов РОНА становилось все сложнее. В августе 1943 г., когда в округе началась эвакуация, этот процесс приобрел настолько выпуклые формы, что немецкая контрразведка была вынуждена установить круглосуточное наблюдение за бригадой. За любые разговоры на антифашистские темы, как передавала агентура партизан, солдатам грозил расстрел ${ }^{169}$.

В своем исследовании А. Даллин утверждает, что во время переброски бригады в Лепель «не было отмечено массового дезертирства» ${ }^{170}$. С этой точкой зрения трудно согласиться. Дезертирство из соединения началось еще до отправки основных сил в Белоруссию. Так, лишь в одном из полков бригады за месяц - с 18 августа до 18 сентября 1943 г. - на сторону партизан перешли 500 солдат, из которых 350 человек сбежали по дороге в Лепель, а остальные 150 - ушли к партизанам по прибытии на место ${ }^{171}$.

\footnotetext{
165 РГАСПИ. Ф. 69. ОП. 1. Д. 750. Л. 106.

166 HPSSS. Schedule B, Vol. 11, Case 321... P. 8.

167 Ковалев Б.Н. Нацистская оккупация и коллаборационизм в России, 1941-1944. М., 2004. C. 151.

168 Партизаны Брянщины. Сборник документов и материалов о Брянском партизанском крае в годы Великой Отечественной войны. Тула, 1970. С. 259.

169 РГАСПИ. Ф. 69. ОП. 1. Д. 912. Л. 131.

170 Даллин А. Указ. соч. С. 50.

171 РГАСПИ. Ф. 69. Оп. 1. Д. 22. Л. 106.
} 
Согласно данным органов госбезопасности СССР, только в июле-августе 1943 г. из бригады РОНА перешли на сторону Красной Армии более 700 человек ${ }^{172}$.

Когда «народники» ступили на белорусскую землю, первыми на сторону партизан 26 августа 1943 г. перешли так называемые «квартирьеры»- 24 человека с вооружением, включенные в бригаду Уткина. За ними дезертировала рота Пащенко. Затем, после того как основная часть РОНА прибыла в Белоруссию, командиры партизанских бригад Леонов и Кириллов связались с командиром 2-го полка Тарасовым, который согласился перейти к народным мстителям вместе со своей частью, но перед этим намеревался уничтожить гарнизон в Сенно и захватить склад с боеприпасами.

15 сентября 1943 г. перешла в полном составе рота капитана Проваторова. Ожидалось, что вскоре перейдет и полк Тарасова, но об этих планах стало известно немцам. Германские органы приняли решение разоружить батальоны 2-го полка. После серьезной вооруженной стычки немцам удалось добиться своей цели: общего перехода солдат не состоялось. Однако в тот день из гарнизона Сенно ушли 264 человека (7-й батальон и часть 4-го батальона РОНА) ${ }^{173}$.

На этом, однако, переходы не закончились. Из 2-го полка в лес ушли еще 27 человек вместе с капитаном Г. Малаховым, а затем 126 человек из разных батальонов тарасовского полка. 25 сентября дезертировали более 30 танкистов из бронедивизиона ${ }^{174}$. В те же самые дни в лес сбежали 50 солдат из артиллерийской батареи. В итоге, как отмечали партизаны в донесении, в сентябре 1943 г. в бригаду Уткина перешли 89 солдат и офицеров РОНА, в бригаду Данукалова - 51 человек, в бригаду Лобанка - 800 человек. В целом, как показывают документы оперативного отдела Белорусского штаба партизанского движения (БШПД), до 15 октября 1943 г. «перешло на сторону партизан и взято в плен свыше 1500 солдат и офицеров» РОНА. Соединение Каминского потеряло, кроме того, более 500 человек ранеными и убитыми, много автомашин и 10 танков ${ }^{175}$.

За два месяца (август-сентябрь) общая численность бригады РОНА сократилась более чем на две трети. По данным партизанской разведки, на 4 октября 1943 г. база продовольственного снабжения Лепельского округа отпускала Каминскому продукты на 3665 человек ${ }^{176}$.

В декабре 1943 г., когда подводились итоги борьбы с «роновцами», сотрудники оперативного отдела БШПД, подготовившие отчет о деятельности

172 Христоборов В.С. Коллаборационисты отдельно взятого Локотского округа... С. 194.

173 Описание боевых действий партизан Белоруссии. Из сборника БШПД, 1944 г. // РГАСПИ. Ф. 625. Оп. 1. Д. 45. Л. 289, 340.

174 РГАСПИ. Ф. 69. Оп. 1. Д. 22. Л. 169.

175 РГАСПИ. Ф. 625. Оп. 1. Д. 45. Л. 341.

176 РГАСПИ. Ф. 69. Оп. 1. Д. 22. Л. 127. 
белорусских партизан, отметили: «Только за сентябрь и первую декаду декабря 1943 г. бригадами Дубровского, Лобанок, Мельникова, Уткина, Данукалова, Леонова, Романова и Кириллова на шоссейных дорогах и большаках уничтожено: 261 автомашина, 10 танков, одна танкетка и одна бронемашина из подразделений Каминского. Активными боевыми действиями партизан в сочетании с агентурно-агитационной работой по разложению формирований изменника Каминского сорваны планы по проведению крупной операции против партизан Лепельского, Ушачского, Чашникского и Сенненского районов» ${ }^{177}$.

Постоянные переходы на сторону партизан повлекли за собой усиление карательных мер. Как уже было не раз, Каминский жестоко расправился с мятежниками. В газете РОНА «Боевой путь» появилась статья, где, в частности, говорилось: «Гнусная банда отбросов человеческого общества, воспитанная кремлевским тираном, поймана с поличным... Не подлежит сомнению, что весь личный состав бригады единодушно одобрит решение военно-полевого суда, приговорившего Тарасова к самой позорной смерти через повешение, а его пособников к расстрелу» ${ }^{178}$.

По сообщению партизанских разведчиков, кроме Тарасова и его приближенных, были повешены 30 солдат, не успевших уйти в партизаны, а также были казнены 50 семей бывших бойцов РОНА, воевавших уже на советской стороне ${ }^{179}$.

С помощью террора Каминскому удалось замедлить процесс разложения коллаборационистского соединения. Чтобы восстановить боевой состав бригады, был проведен набор из числа белорусских полицейских. Кроме того, была усилена контрпропаганда с использованием газет и листовок. Тем не менее, формирование Каминского не выглядело монолитным. Несмотря на предпринятые меры, деморализация в РОНА возрастала ${ }^{180}$. «Наше положение в Белоруссии было хаотичным, - вспоминал один из бывших членов бригады. - Отдельные воинские подразделения и командиры имели контакты с партизанами ${ }^{181}$. Моральное состояние большинства офицеров также оставляло желать лучшего. Я вспоминаю, например, о майоре Турлакове, который зимой 1943-1944 гг. был приглашен вместе с подполковником Белаем в Берлин. Когда он увидел там жестокое обращение и жизненные условия

177 РГАСПИ. Ф. 625. Оп. 1. Д. 45. Л. 341.

178 Приговор суда - приговор народа // «Боевой путь» (Лепель). 1943. № 2, 9 октября. С. 1.

179 РГАСПИ. Ф. 625. Оп. 1. Д. 45. Л. 341.

${ }^{180}$ Hesse E. Op. cit. S. 176.

181 Начальник разведки бригады «Дубова» С.В. Маркевич вспоминал: «Не углубляясь в детали, скажу, что удалось выйти на заместителя комбрига РОНА по разведке Бориса Краснощекова, который в последующем сумел похитить из штаба армии план уничтожения партизан Полоцко-Лепельской зоны». Цит. по: Маркевич С.В. Рейсы бессмертия // Авиация - партизанам: 1941-1944. Документы и воспоминания. Минск, 2005. С. 228-229. 
у русских военнопленных и восточных рабочих, он возвратился сломанным. В последующем разговоре с Каминским он сорвал с себя погоны и награды (в том числе Железный крест I класса) и заявил, что он, скорее всего, стоит на неправильной стороне! Каминский и я успокаивали его, однако не смогли предотвратить того, что весной 1944 г. Турлаков, сидевший на танке, неожиданно соскочил с него, выбежал перед ним и таким образом положил конец своей жизни» ${ }^{182}$.

Крайне негативно повлиял на бойцов бригады и беженцев переезд из Лепеля в Дятлов. Многие, как передают источники, были потрясены этим решением, чувствовали себя беглецами и все больше приходили к пониманию того, что война проиграна ${ }^{183}$. Тогда уже, как подчеркивает К. Герлах, невозможно было говорить о каком-либо длительном поселении на новом месте ${ }^{184}$. От Каминского хотели только одного - чтобы его бригада, как и раньше, боролась с партизанами. Порою «народникам» это удавалось, но общее моральное состояние неизменно падало. Финалом всего стало Варшавское восстание, полностью обнажившее самые темные стороны формирования Каминского.

Оценивая репрессивно-карательную деятельность вооруженных формирований Локотского окружного самоуправления, необходимо сказать о том, что в отношении гражданского населения администрация Каминского действовала, исходя из ситуации.

Как правило, те, кто лояльно относился к «новому порядку», до определенного момента могли вести сравнительно сносную (в условиях войны и оккупации) жизнь. Однако самые суровые меры применялись к тем, кто был даже заподозрен в связях с партизанами и в симпатиях к советской власти. В эту категорию, как мы показали выше, в принципе, мог попасть любой человек, включая самых высокопоставленных командиров и чиновников автономии.

Подразделения бригады Каминского нередко совершали преступления самостоятельно, хотя их число заметно уступает акциям, которые проводились совместно с немцами и венграми. Тем не менее, и в том, и в другом случае личный состав РОНА занимался истреблением нелояльного гражданского населения.

Практика заложничества, распространенная на территории Локотского и Лепельского округов, имела паллиативный характер. Признать ее эффективной вряд ли возможно, поскольку она не могла замедлить развитие партизанского движения на юге Брянщины. Акции такого рода, скорее, прибавили

182 Цит. по: Michaelis R. Russen in der Waffen-SS... S. 34.

183 Ibid.

184 Gerlach C. Op. cit. S. 1053. 
проблем автономии, чем помогли их решить, так как суровое наказание невиновных людей вызывало у населения отрицательную реакцию.

Во время процессов фильтрации гражданских лиц (в ходе антипартизанских операций) происходило уничтожение тех, кого подозревали в связях с партизанами. Учитывая насильственный характер этих мероприятий, процесс фильтрации представляется одним из основных элементов карательной деятельности местного самоуправления.

Применяя различные средства для достижения своих целей, Каминский и его подчиненные вели беспощадную борьбу против партизан и твердо придерживались курса на удаление из своего «нового общества» евреев. Периодические издания округа активно занимались пропагандой антисемитизма и подталкивали личный состав вооруженных отрядов к совершению преступлений на национальной почве. В районах автономии было уничтожено несколько сот евреев и ликвидировано два гетто.

Руководство самоуправления очень жестоко расправлялось с теми, кто пытался оказывать ему сопротивление. Казням подвергались как бойцы батальонов, так и их семьи, если вскрывались факты их тайных контактов с подпольщиками и партизанами. Суровые наказания, введенные в бригаде, удерживали соединение Каминского от распада, но не могли воспрепятствовать переходам на советскую сторону, которые начались еще в момент формирования первых подразделений народной милиции. За время существования коллаборационистского соединения из его рядов, по нашим подсчетам, дезертировало от трех до четырех тысяч человек. За попытки перехода к партизанам - по приблизительным оценкам - было казнено от 300 до 400 бойцов РОНА и членов их семей.

Продолжительная по времени деятельность каминцев во многом обусловлена той ролью, которую сыграл в этой истории сам обер-бургомистр. Именно он был инициатором локальных карательных акций, публичных казней и расправ, совершавшихся в округе. Политика Каминского базировалась на полном подчинении его воле, что позволило ему добиться немалых результатов и, вместе с тем, пробудило к нему жгучую ненависть со стороны его противников. Устанавливая с помощью кнута и пряника свой порядок, он стремился все подчинить себе, даже не боялся вступать в конфликты со своими немецкими кураторами, если видел ущемление своих интересов. Террор для обер-бургомистра был важным средством укрепления единоличной власти. И он прибегал к нему довольно часто, так как это был один из способов его самоутверждения.

В идейном плане Каминский ориентировался на немецкий национал-социализм, на основе которого пытался развернуть новую идеологию русского национализма. Эта идеология так и не обрела законченной формы. Зато в практическом плане Каминскому больше сопутствовала удача, только цена этих опытов оказалась высокой - десятки тысяч человеческих жизней. 


\title{
Represyjna działalność brygady Kamińskiego na okupowanych terenach ZSRR w latach 1941-1944
}

Artykuł porusza praktycznie zapomniany epizod historii w dziejach emigracji rosyjskiej. Kwerendy archiwalne pozwoliły ustalić kwestie zaangażowania porewolucyjnych emigrantów rosyjskich $\mathrm{w}$ walkę z Niemcami w czasie II wojny światowej na terenie okupowanych ziem polskich. Osoby wymienione $\mathrm{w}$ tym krótkim artykule są przykładem nieszablonowego postępowania. Piszący te słowa jeszcze roku temu na pytanie po której stronie angażowali się rosyjscy emigranci w czasie II wojny światowej - odpowiadał: Po niemieckiej przeciwko bolszewikom. Pierwsze wiadomości przyszły z rozmowami ze specjalistami i sugestiami lektur, a poznanie świadka historii, pamiętającej i widzącej na własne oczy opisane tu wydarzenia to wartość nieoceniona. Artykuł ten przypomina o losach antykomunistycznych emigrantów rosyjskich tzw. „białych”, zaangażowanych w walkę z narodowosocjalistycznymi Niemcami i Austriakami. Są to przykłady chwalebne - jak całkowicie zapomniani bracia Tumanowowie (o których nawet w Muzeum Powstania Warszawskiego nikt nie wiedział) czy Jurasow, Kuroczkin i Tryfonow, walczący w Nowogródzkiej i Wileńskiej AK. Artykuł nie wyczerpuje tematu, bo należałoby jeszcze wspomnieć Aleksandra Grigorowicza, Jana Szaliłowa ps. „Renek”, Dmitrija Sokolcowa czy Irenę Tamarę Misztal (Tamarę Piotuch) oraz innych. Konspirowali i walczyli jakby pod prąd tendencjom, naprzeciw łatwiejszego życia a wręcz z jego narażeniem. Ten pasjonujący i nieznany epizod historii drugowojennej wymaga głębszego usystematyzowania i sprawdzenia wielu biografii spośród przedstawicieli przedwojennej porewolucyjnej diaspory rosyjskiej, żyjącej w II RP, a w czasie wojny walczącej „za wolność naszą i waszą”.

\section{Repressive activity of Kaminski's brigade in the occupied territories of the USSR in 1941-1944}

\begin{abstract}
The Kaminski Brigade, known also as the Russian National Liberation Army (Russkaya Osvoboditelnaya Narodnaya Armiya, RONA), together with the 29th Waffen Grenadier Division of the SS occupy a special place in the history of collaborationist formations created in the territories of the USSR occupied by the Nazis. The division was not a propaganda unit, unlike the Russian National Liberation Army of Gen. Andrey Vlasov, which was intended to manifest the support of European nations to Nazi Germany. It was a combat unit, effective in fights against Soviet guerilla forces in the occupied territories. Its effectiveness could be testified by the rank of Waffen-Brigadeführer der SS awarded to its commander Bronislav Kaminski. The German High Command granted him broad operational autonomy within the districts of Orlov and Kursk.

Finally, the RONA forces were pushed to the west. They withdrew to the territory of occupied Belarus, where they successfully fought against guerrilla troops and committed numerous crimes against local civilians. For their contributions, the brigade was incorporated to the structures of the Waffen-SS, being their first Russian division ever. In 1944, together with the 29th Waffen Grenadier Division of the SS, the unit was used to crush the Warsaw Uprising.
\end{abstract}




\section{Библиография}

Cooper M. Nazi war against soviet partisans. New York, 1979.

Gerlach C. Kalkulierte Morde. Die deutsche Wirtschafts- und Vernichtungspolitik in Weißrußland 1941 bis 1944. Hamburg, 1999.

Hasenclever J. Wehrmacht und Besatzungspolitik in der Sowjetunion. Die Befehlshaber der rückwärtigen Heeresgebiete 1941-1943. Paderborn, 2010.

Hesse E. Der sowjetrussische Partisanenkrieg 1941 bis 1944 im Spigel deutscher Kampfweisungen und Befehle. Göttingen, 1969.

Hinze R. Ostfront 1944. Suttgart, 2011.

Howell M.E. The Soviet Partisan Movement, 1941-1944. Washington, 1956.

Klausch H.-P. Antifaschisten in SS-Uniform. Schicksal und Widerstand der deutschen politischen KZ-Häftlinge, Zuchthaus- und Wehrmachtsgefangenen in der SS-Sonderformation Dirlewanger. Bremen, 1993.

Mallmann K.-M., Angrick A., Matthäus J., Cüppers M. Deutsche Besatzungsherrschaft in der UdSSR 1941-1945. Dokumente der Einsatzgruppen in der Sowjetunion. Bd. II. Darmstadt, 2013.

Michaelis R. The Kaminski Brigade. Schiffer Military History, 2011.

Neitzel H. Rear Area Security in Russia. Washington, 1951.

Pohl D. Die Herrschaft der Wehrmacht. Deutsche Militärbesatzung und einheimische Bevölkerung inder Sowjetunion. Frankfurt-am-Main, 2011.

Prag W., Jacobmeyer W. Das Diensttagebuch des deutschen Generalgouverneurs in Polen 1939-1945. Stuttgart, 1975.

Stopper S. Das Brjansker Gebiet unter der Besatzungsherrschaft der Wehrmacht 1941 bis 1943. Dissertation zur Erlangung de akademischen Grades Doctor philosophiae. Berlin, 2012.

Азясский Н. О вкладе партизан в разгром группы армий «Центр» // «Военно-исторический журнал» (Москва). 1980. № 2.

Алексеев В.М. Варшавское восстание. Варшава в борьбе против гитлеровских захватчиков. СПб., 1999.

Альтман И.А. Жертвы ненависти. М., 2002.

Анищенко Е. Партизанская республика. Героические повествования о народных мстителях Навлинского района Брянщины. Тула, 1992.

Анищенко Е.Н. Через толщу лет. Документальные очерки о партизанах и подпольщиках Брянщины. Тула, 1996.

Веревкин С.И. Самая запретная книга о Второй мировой. Была ли альтернатива Сталину? М., 2009. с.; Христофоров В.С. Коллаборационисты отдельно взятого Локотского округа // 65 лет Великой Победы. В 6 т. Т. 4: Другое лицо войны. М., 2010.

Гаврилкин Г.А. Непокоренный суземский край (Хроника партизанской битвы) // Поклонимся великим тем годам... Москва-Суземка, 2005.

Гребень Е. Русская национальная идея как элемент террора коллаборационистских властей // Нацистская война на уничтожение на северо-западе СССР: региональный аспект. Материалы международной научной конференции (Псков, 10-11 декабря 2009 года). М., 2010.

Даллин А. Бригада Каминского. М., 2011.

Дробязко С.И. Локотский автономный округ и Русская Освободительная Народная Армия // Материалы по истории Русского Освободительного Движения: сборник статей, документов и материалов. Вып. 2. М., 1998.

Ермолов И.Г. История Локотского округа и Русской освободительной народной армии. Орел, 2008.

Ермолов И.Г. Русское государство в немецком тылу. История Локотского самоуправления. 1941-1943. М., 2009. 
Жилянин Я., Поздняков Н., Лузгин В. Без линии фронта. Минск, 1975.

Жуков Д.А., Ковтун И.И. 29-я гренадерская дивизия СС «Каминский». М., 2009.

Жуков Д.А., Ковтун И.И. Антисемитская пропаганда на оккупированных территориях РСФСР, 1941-1944 гг. Ростов-на-Дону, 2015.

Забельский М.А. На «малой» земле // Незримого фронта солдаты. Сборник воспоминаний. Тула, 1971.

Ковалев Б.Н. Нацистская оккупация и коллаборационизм в России, 1941-1944. М., 2004.

Коровин В.В. Партизанское движение на территории Курской области в 1941-1943 гг. Курск, 2006.

Макаров В., Христофоров В. Дети генерала Шмидта. Миф о «Локотской альтернативе» // «Родина» (Москва). 2006. № 10.

Манжосов А.Н. Политика репрессий фашистских оккупантов на территории Курской области (1941-1943 гг.) // «Курский край» (Курск). 1999. № 4 (7).

Маркевич С.В. Рейсы бессмертия // Авиация - партизанам: 1941-1944. Документы и воспоминания. Минск, 2005.

Морозов В.К. Врагу от нас не уйти // За линией фронта. Очерки. Тула, 1968.

Мюллер Р.-Д. На стороне вермахта. Иностранные пособники Гитлера во время «крестового похода против большевизма» 1940-1945 гг. М., 2012.

Пономаренко П.К. Всенародная борьба в тылу немецко-фашистских захватчиков 19411944. М., 1986.

Розенблат Е.С. Холокост и антифашистское еврейское сопротивление на белорусской земле // Беларусь 1941-1945: Подвиг. Трагедия. Память. В 2 кн. Кн. 1. Минск, 2010.

Рябоконь М.В. Против партизан Брянщины // «Военно-исторический журнал» (Москва). 2004. № 4 (528).

Татаренко А. Недозволенная память: Западная Беларусь в документах и фактах: 19211954. СПб., 2006.

Федосюткин А.Д. На земле железной // Народные мстители. Воспоминания курских и белгородских партизан и подпольщиков. Воронеж, 1975.

Черняков Д.И. «Все евреи, в том числе и маленькие дети... расстреляны». Полицейские формирования Брянщины на службе у гитлеровских захватчиков (1941 - 1943 гг.) // «Военно-исторический журнал». 2011. № 5 (613).

Черняков Д.И. Локотская газета «Голос народа» на службе у нацистской пропаганды. 1942-1943 гг. // «Вопросы истории» (Москва), 2010. № 5.

Штоппер С. Смерть немецким оккупантам? О военной эффективности партизанского движения в немецко-советской войне (по немецким источникам на материалах Брянского региона) // Доклады академии военных наук. № 3 (38). Саратов, 2009.

\section{Информация об авторах:}

Российские историки Д.А. Жуков и И.И. Ковтун более 15 лет занимаются изучением вопросов русского коллаборационизма и немецкой оккупационной политики на захваченных территориях СССР в годы Второй мировой войны. За время исследовательской деятельности авторами было подготовлено большое количество научных публикаций и более 10 книг, в том числе «1-я Русская бригада СС «Дружина», «Русские эсэсовцы», «Русская освободительная народная армия», «Антисемитская пропаганда на оккупированных территориях РСФСР, 1941-1944», Полицаи. История. Судьбы. Преступления» и др. В настоящее время авторы продолжают изучение темы бригады РОНА и готовят к выходу в свет новой научной работы. (ivan_kovtun-97@mail.ru) 
Russian historians D.A. Zhukov and I.I. Kovtun has been studying the issues of Russian collaborationism and German occupation policy for more than 15 years in the occupied territories of the USSR during the Second World War. During the period of research, the authors prepared a large number of scientific publications and more than 10 books, including "1-я Русская бригада СС “Дружина”, “Русские эсэсовцы”, “Русская освободительная народная армия”, “Антисемитская пропаганда на оккупированных территориях РСФСР, 1941-1944”, “Полицаи. История. Судьбы. Преступления". At present the authors continue to study the topic of the RONA brigade and are preparing for the publication of a new scientific work (Ivan_kovtun-97@mail.ru) 